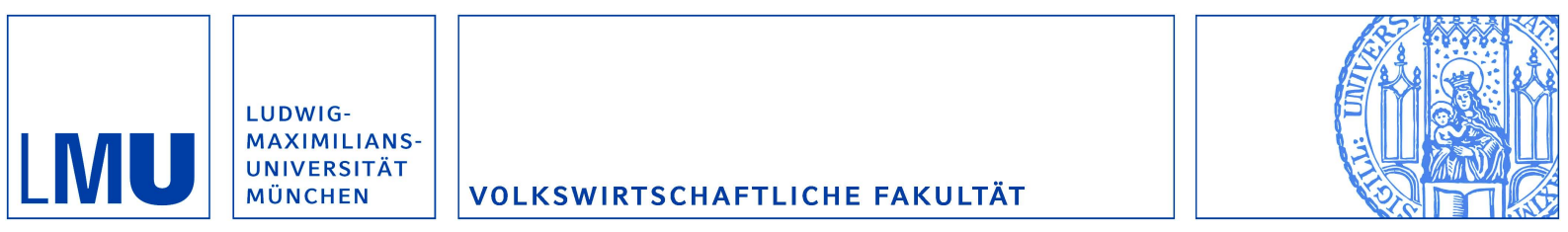

Mohler, Lukas and Seitz, Michael:

The Gains from Variety in the European Union

Munich Discussion Paper No. 2010-24

Department of Economics

University of Munich

Volkswirtschaftliche Fakultät

Ludwig-Maximilians-Universität München

Online at https://doi.org/10.5282/ubm/epub. 11477 


\title{
The Gains from Variety in the European Union
}

\author{
Lukas Mohler* \\ Faculty of Business and Economics, University of Basel, Peter Merian-Weg 6, 4002 Basel, Switzerland \\ Michael Seitz ${ }^{\dagger}$ \\ Department of Economics, Ludwig-Maximilians-University of Munich, Ludwigsstrasse 28, 80539 Munich, Germany
}

March 2010

\begin{abstract}
Over the last decade, European Union members have experienced a dramatic increase in imports. This increase was accompanied by a strong growth in the number of imported goods and trading partners, indicating positive welfare gains for consumers via an extended set of consumption possibilities, as pointed out in the "New Trade Theory". In this paper, we apply the methodology developed by Feenstra (1994) and Broda and Weinstein (2006) to estimate structurally the gains from imported variety for the 27 countries of the European Union using highly disaggregated trade data at the HTS-8 level from Eurostat for the period of 1999 to 2008. Our results show that, within the European Union, especially "newer" and smaller member states exhibit high gains from newly imported varieties. Furthermore, we find that the vast majority of the gains from variety for consumers stem from intra-European Union trade.
\end{abstract}

JEL classification: F12, F14;

Keywords: European Union, Welfare Gains from Trade, Trade in Variety;

\footnotetext{
*Tel.: +41 61267 0770; fax +41612671316; Email address: Lukas.Mohler@unibas.ch

†Corresponding author. Tel.: +49 892180 6286; fax +49 892180 6227; Email address: Michael.Seitz@lrz.unimuenchen.de
} 


\section{Introduction}

The European Union with its 27 member states today constitutes the largest single market in the world. Over the past decade, several historical events have deepened the economic integration of the economies within the European Union but also of the member states into the world economy, resulting in a strong increase in trade flows. First, the euro was introduced as book money in 1999 and today is the official currency of 16 European Union member states. Second, the transition of the Eastern European economies from planned economies to market economies after the fall of the Iron Curtain was accompanied by a surge and redirection of trade flows towards the "old" member states as well as a surge of trade between Eastern European countries. This transition finally led to the eastern enlargement in 2004, when ten new member states joined the European Union, followed by Romania and Bulgaria in 2007. Finally, the European Union and its member states were confronted with the integration of fast-growing emerging markets into the world trading system over the last decade, with China and other East Asian economies at the forefront. This dynamic process of economic integration on the one hand caused more competition and new challenges for the European member states and European firms. On the other hand the integration process was accompanied by a dramatic increase in internal and external trade flows for all the member states. One important aspect of this phenomenon is the positive effect on consumer welfare via increased imports and an extended choice set of available varieties for consumers. From 1999 to 2008 the total value of imports for all countries has more than doubled. At the same time, the mean number of supplying countries within an average product category has increased by about $15 \%$, while the number of imported product categories has stayed roughly constant. In sum, about $60 \%$ in the increase of total imports can be attributed to the establishment of new trade linkages with new goods and/or new trading partners, indicating high gains for consumers as a result of newly available products.

Since the pioneering work of Krugman $(1979,1980,1981)$ the "love for variety" motive and its implications for consumer welfare have been a key element of the "New Trade Theory". Based on a monopolistic competition model, first outlined by Spence (1976) and Dixit and Stiglitz (1977), where a single good is available in different varieties, these models predict that trade leads to an increased number of varieties available for consumers. In combination with a constant elasticity of substitution (CES) utility function, trade generates positive effects for consumer welfare via the availability of more varieties of one good. Since then, economists have tried to quantify empirically the gains for consumers from newly imported varieties. In his seminal contribution, Feenstra (1994) was the first to assess empirically the impact of new and disappearing varieties for a single imported good. Based on the theoretical framework of the New Trade Theory, Feenstra (1994) developed an artificial price index to measure the impact of traded varieties on consumer welfare. The idea is that new varieties lower the price index, while disappearing varieties increase the index, where the magnitude depends on the substitutability between the varieties and their expenditure share. Broda and Weinstein (2006) extend the approach of Feenstra (1994) and construct an aggregate price index using the full set of imported products to compute the import price index bias resulting from the omission of new and disappearing varieties. This approach allows them to quantify the overall impact of imported varieties on consumer welfare for the United States for the period from 1972 to 2001. Using highly disaggregated trade data, and the assumption that goods are differentiated across countries, they show that the unmeasured growth in product variety has been an important source of welfare gains. ${ }^{1}$ Their results indicate an upward bias of the conventional price index of the magnitude of $1.2 \%$ per year which translates into an overall effect of $2.6 \%$ of GDP for the overall period or put differently, consumers are willing to pay roughly $0.1 \%$ of their annual income to have access to a larger set of goods and varieties.

In this contribution we adopt the methodology of Broda and Weinstein (2006) to estimate structurally the gains from imported variety for all 27 European Union member states for the period from 1999 to 2008 by exploring a rich dataset of highly disaggregated trade data at the HS- 8 level which allows us to identify over 10,000 different product categories: to our best knowledge this has not been used before in another study. The effects on consumer welfare of newly available products are in particular interesting for European economies, since the European Union consists of many small and medium-sized economies with high import shares and a high degree of political and economic integration within the European Union as well as in the world economy. In addition, our study of a set of countries allows us

\footnotetext{
${ }^{1}$ The definition that goods are differentiated across countries is based on the theoretical framework of Armington (1969). Here, a variety is simply a particular good produced by a particular country, e.g., French wine.
} 
to analyse and interpret results across countries, adding another dimension to this approach. We follow Broda and Weinstein (2006), and construct an artificial import price index for each country. In a first step we estimate a total of approximately 170,000 elasticities of substitution, one for each imported good of each country. In a second step we use these elasticities to compute a correction term for each product. This term captures the effect on the price index that is due to the change in the variety set. Based on the structural assumption of a Krugman (1980) style economy, we finally calculate the gains from variety for each single member state. Furthermore, we extend the approach of Broda and Weinstein (2006) which allows us to calculate the import price index for European Union internal and external imports. This enables us to identify which trade flows contribute most to the gains from variety for each member state. Using our highly disaggregated trade data, we also provide extensive descriptive statistics about the number of trading partners and traded products for the European member states, which allows us to gain new insights into the trade integration process of all the member states. Finally, we provide some new robustness measures to build further confidence in our results. Our results can be summarized as follows: for most countries the biases and hence the gains from variety are positive. However, the results differ across countries and three different groups can be identified. First, for the largest four economies in the European Union in terms of GDP, the impact of traded variety is small for the considered period. This can be explained by smaller import shares and the fact that these economies have already been strongly integrated into the European Union and the world market in 1999, which is our base year. Secondly, for all the smaller "old" member states we find modestly positive gains from imported variety. Finally, for the "newer" member states of the European Union, with the exception of Malta, the gains are strongly positive, mostly larger than 1\% of GDP. This result reflects the effects of the ongoing integration of these countries into the European single market and into the world trading system as well as their higher growth rates and higher import shares. For example, variety gains for Estonia sum up to $2.8 \%$ of GDP, which is of the same magnitude as Broda and Weinstein (2006) find for the United States for their much longer period from 1972 to 2001. Our results show that especially for fast-growing, less-developed and smaller countries, the establishment of new trade linkages and the importing of new varieties are an important source of welfare gains via trade. We also find that for most countries about $70 \%$ of the gains stem from intra-European trade, emphasizing the positive effects and importance of European integration. Third, descriptive statistics of the estimated elasticities of substitution indicate that they do not differ systematically across countries, which is interesting, given the different sizes of the economies.

Our paper contributes to two strands of the empirical trade literature. First, beside the approaches of Feenstra (1994) and Broda and Weinstein (2006) several other studies have tried to evaluate the effects of new varieties on consumer welfare and the role of trade. ${ }^{2}$ A first attempt was made by Feenstra (1992). He shows in a numerical example how trade barriers can affect the number of available products and reduce consumer welfare. Following the idea of Feenstra (1992), Romer (1994) calibrates a model with fixed export costs and finds that a substantial reduction in trade barriers will lead to more exported varieties, resulting in an increase of GDP of up to 20\%. Using a similar approach Klenow and Rodríguez-Clare (1997) construct and calibrate a general equilibrium model with detailed Costa Rican trade data to quantify the impact of trade restrictions on welfare. Their results suggest that the gains from trade liberalization can be higher compared with traditional models if the effects of traded variety are taken into account. In an extension, Arkolakis et al. (2008) provide a more detailed analysis of the Costa Rican trade liberalization and find that the effect of trade liberalization on product variety is relatively small, since new products are imported in small quantities. Furthermore, Broda and Weinstein (2004) document the rapid growth in product variety over the last decade in world trade and point to the important effects on consumer welfare. ${ }^{3}{ }^{4}$ Although these studies made important first steps in analysing and understanding the impact of new traded varieties, their methodologies and data rest on strict assumptions and provide an unprecise measure compared with the more sophisticated approach of Broda and Weinstein (2006). Therefore, more recent papers rely on the methodology first proposed by Feenstra (1994) and extended by Broda and Weinstein (2006). Using detailed market data

\footnotetext{
${ }^{2}$ For a more microeconomic perspective on the effects of new varieties on consumer gains see Hausman (1981), Hausman (1994), and Trajtenberg (1989).

${ }^{3}$ For a theoretical explanation of the increase in traded varieties also see Yi (2003), Melitz (2003), and Bernard et al. (2003).

${ }^{4}$ The increase of product variety over the last decades can also be observed at the national level. Bils and Klenow (2001) find a strong increase in 106 product categories for the U.S especially over the last 20 years.
} 
about the U.S. automobile market Blonigen and Soderbery (2009) are able to estimate a more precise measure of welfare gains and show that the Armington assumption, that goods are only differentiated across countries, hides significant welfare gains. They find that the estimated impact of new net varieties on consumer welfare is doubled in magnitude when compared with conventional import data. Using similar methodologies and data another strand of literature emphasizes the positive effect of increased import variety on productivity, including Feenstra and Markusen (1994), Broda et al. (2006), and Feenstra and Kee (2008). Considering the European case, Funke and Ruhwedel (2005) provide an empirical analysis of disaggregated trade data on export variety and economic growth in the Eastern European countries. Their analysis shows a high correlation between increased imported variety and economic growth. Second, while the European integration process has received substantial interest in the literature, the analysis of European Union trade flows and their positive effects on consumer has been scarce. Smith and Venables (1988) made an important first step in evaluating the positive effects of a single market in the European Union. Based on a Krugman (1979) model, they show in a numerical experiment that the creation of a single market has a strong pro-competitive effect at the industry level, generating large welfare gains for its member states of up to $4 \%$ of GDP. In the European trade literature three prominent lines can be identified. First, several studies have tried to quantify the positive effect of the introduction of the euro on trade: see Baldwin (2006) for a survey. Second, researchers have studied the effect of European integration and the role of national borders in intra-European trade flows, including Nitsch (2000) and Chen (2004). Finally, Buch and Piazolo (2001) and Manchin and Pinna (2009) study the implications of the Eastern European enlargement in 2004 on the growth and redirection of trade flows towards the European Union. All these studies rather build on aggregated trade data and evaluate the extent to which the composition and volume of trade flows are changing, but do not analyse highly disaggregated trade data which is also a novelty of our approach. Finally, all these papers neglect the potential positive effect on consumer welfare, which is at the heart of our contribution.

The rest of the paper is organized in the following sections. In section 2 we describe the dataset and provide detailed descriptive statistics of disaggregated trade data and the number of imported varieties for all the member states. Section 3 briefly reviews the methodology developed by Feenstra (1994) and Broda and Weinstein (2006) to account for variety changes in price indices before turning to section 4 which presents the results and interpretation for each member state. Section 5 concludes.

\section{Descriptive Statistics}

To quantify empirically the positive effects on consumer welfare from the availability of new imported products, our analysis requires highly detailed product information on the quantity and prices of imported goods. Therefore our empirical analysis uses the database from Eurostat which consists of highly disaggregated trade data defined at the HS-8 level for all EU-27 member states for the period from 1999 to 2008. In this data set about 10,000 products are classified, for which data on the value and tons of imports are available, which allows us to calculate unit prices for each product. From this database we collect information on the imports for each single member state from all the trading partners in the world. We use quarterly data from the first quarter of 1999 to the first quarter of 2008 to rule out potential seasonality effects. The richness of this data set allows us to provide a precise estimate of the gains from variety, which is robust to several extensions as discussed in the following sections. Table 1 provides some detailed information on the development of the product categories available from this data set over time. For the period from 1999 to 2008 the total number of classified products amount to 13,234 . At the same time the number of classified products decreased from 10,428 to 9,699 . In total, 2,950 new products were introduced and 3,838 were deleted, resulting in a total net change of 6,788 classified, products for the overall period. It is also obvious that for each year the numbers new and excluded products are roughly equal, while the absolute value of reclassification varies over time. Especially for the years 2002, 2006, and 2007 large product category changes can be observed. ${ }^{5}$

\footnotetext{
${ }^{5}$ This is due to reclassifications that appear regularly. The empirical approach presented below is robust towards such reclassifications of products, as explained by Feenstra (1991).
} 
Table 1: Summary statistics on product codes at the HS-8 level for the period from 1999 to 2008

\begin{tabular}{rrrrrr}
\hline \hline Year & $\begin{array}{c}\text { Total number } \\
\text { of product codes } \\
(1)\end{array}$ & $\begin{array}{c}\text { New } \\
\text { product codes } \\
(2)\end{array}$ & $\begin{array}{c}\text { Deleted } \\
\text { product codes } \\
(3)\end{array}$ & $\begin{array}{c}\text { Total } \\
\text { change } \\
(4)\end{array}$ & $\begin{array}{c}\text { Net } \\
\text { change }\end{array}$ \\
\hline 1999 & 10,428 & 144 & 303 & 447 & -159 \\
2000 & 10,314 & 109 & 223 & 332 & -114 \\
2001 & 10,274 & 50 & 90 & 140 & -40 \\
2002 & 10,400 & 780 & 654 & 1,434 & 126 \\
2003 & 10,404 & 19 & 15 & 34 & 4 \\
2004 & 10,174 & 273 & 503 & 776 & -230 \\
2005 & 10,096 & 97 & 175 & 272 & -78 \\
2006 & 9,842 & 486 & 740 & 1,226 & -254 \\
2007 & 9,720 & 917 & 1,039 & 1,956 & -122 \\
2008 & 9,699 & 75 & 96 & 171 & -21 \\
\hline \hline
\end{tabular}

\subsection{Analysis of Aggregated Trade Flows}

For our descriptive analysis we start with aggregated trade data at the European level before turning to the more disaggregated country level. The dynamic economic integration process over the last decade, within the European Union as well as at the global level, has led to a dramatic increase in imports for all the member states. From row one in column 1 and 2 in Table 2 we can see that aggregated imports of the European Union member states from all the trading partners have more than doubled from 487 billion euros in the first quarter of 1999 to 979 billion euros in the first quarter of 2008. Since one focus of our study is trade within the European Union we split up imports by European Union, internal imports and imports from the rest of the world (external imports) in row two and three. We can see that the European Union internal trade flows account for approximately $60 \%$ of all the imports, underlining the importance of internal European Union trade. Both internal and external import flows have grown at rapid rates and roughly doubled in this period, while external trade flows have grown at a slightly higher rate, resulting in a higher import share of non-European Union imports in 2008, accentuating growing trade with emerging markets like China at the forefront. This strong increase in imports was accompanied by another phenomenon, a strong increase in the number of imported varieties. In our analysis a good is defined as an HS-8 product category. Following Armington (1969), a variety is then assumed to be a particular good from a particular country. Based on this definition we find a strong increase from 1.67 million to 1.97 million imported varieties during the same period. Similarly to the value of imports, about two-thirds of new varieties stem from internal imports. This is interesting, given the relatively small number of potential trading partners for a single product within the European Union, and highlights the importance of intra-European Union trade as a source of new product varieties for consumers.

Given the diverse structure of the European economies and their differences in terms of size (GDP), growth of GDP, absolute imports, and import shares, countries have been affected differently by the integration process. Since in New Trade Theory the absolute size and growth rate of a country are an important determinant of the structure and development of import flows, three different types of countries in the European Union can be identified: ${ }^{6}$ first, the "big four" economies including Germany, Italy, France, and the United Kingdom with the largest GDP in the European Union; second, the eleven "small old" high income member states; third the twelve fast-growing less-developed "new" member states mostly, from Eastern Europe, which joined the European Union in 2004 and 2007, respectively. In columns three to six in table 2 we show descriptive statistics of aggregated imports for each of these three blocks. For all the blocks we can see a strong growth in import volume from both European Union and non-European Union countries, which is highest for the "new member" states. The "big four" account for roughly half of all the imports but only for a quarter of the imported varieties. Despite the strong growth in imports, the number of imported varieties only slightly increased from

\footnotetext{
${ }^{6}$ In the New Trade Theory, the absolute value of trade between two economies depends on the size of both economies.
} 
456,744 to 496,597 , indicating that imports have grown at the intensive margin. ${ }^{7}$ While $65 \%$ of the total imports stem from the EU-27 member states, they only account for $58 \%$ of the imported varieties in 1999, but both shares slightly decreased over time, emphasizing the growing importance of trade with non-European Union member states over the last decade. We obtain a similar picture for the "small old" member states, although internal EU-27 imports on average are even more important for these economies. In contrast to the "big four", imports have also grown along the extensive margin. This increase in traded variety is mainly due to trade with non-European Union members, since in this category the number of imported varieties has grown substantially from 217,793 to 292,638. Finally, for the "new" member states we gain a somewhat different picture. First, trade with other European member states is very important for this group and amounts to approximately $70 \%$ of the total imports. Second, although the trade value from both European Union and non-European Union members in 2008 was roughly four times larger than in 1999, the fact that the number of varieties imported from other European Union countries has grown by $50 \%$ while the number of varieties from the rest of the world has been slightly decreasing is striking.

Table 2: Aggregated imports for each subgroup

\begin{tabular}{lrrrrrrrr}
\hline \hline & \multicolumn{2}{c}{ "All-27" } & \multicolumn{2}{c}{ "Big four" } & \multicolumn{2}{c}{ "Small old" } & \multicolumn{2}{c}{ "New" } \\
& 1999 & 2008 & 1999 & 2008 & 1999 & 2008 & 1999 & 2008 \\
\hline & \multicolumn{1}{c}{$(1)$} & \multicolumn{1}{c}{$(2)$} & $(3)$ & $(4)$ & $(5)$ & $(6)$ & $(7)$ & $(8)$ \\
\hline Total Imports (bn. euros) & 487 & 979 & 277 & 485 & 179 & 371 & 31 & 122 \\
Total Imports EU-27 (bn. euros) & 159 & 354 & 181 & 299 & 124 & 236 & 21 & 84 \\
Total Imports ROW (bn. euros) & 328 & 624 & 96 & 185 & 55 & 136 & 8 & 33 \\
\hline Imported varieties (th.) & 1,678 & 1,970 & 456 & 496 & 662 & 796 & 558 & 677 \\
Imported varieties EU-27 (th.) & 602 & 699 & 264 & 280 & 445 & 504 & 333 & 447 \\
Imported varieties ROW (th.) & 1,077 & 1,273 & 192 & 216 & 217 & 292 & 191 & 189 \\
\hline \hline
\end{tabular}

Note: All variables are calculated by aggregating each individual variable for each of our defined subgroups.

To obtain a better sense of the forces that have been driving the increase in variety over the last decade Table 3 shows the data by exporting trading partners. Columns one and two of Table 3 rank the top 30 out of 189 trading partners by the total number of exported goods categories to all the European member states. The first column presents the ranking for the first quarter of the year 1999 and the second column the one for the first quarter of the year 2008. In column 3 the rank of the absolute increase in the number of exported product categories over the last decade is displayed. In columns 4 to 6 we conduct the same experiment but now for the total value of exports to all the member states. Interestingly, 18 out of the top 30 supplying countries of exported products and total exports are European member states, despite the European Union's many small and medium-sized economies. This reflects the high degree of economic integration and proximity within Europe. Not surprisingly, the largest four economies of the European Union are also the top suppliers in terms of the number of products and the total exports to the EU-27. However, over time the rank increase in exported product categories has been relatively modest compared with the absolute export values for these countries. In particular, the United Kingdom seems to have profited less from the increased export possibilities over the last decade. Besides, fast-growing emerging markets like China, India and Turkey, and in particular small and medium- sized European countries have been the driving force of new product suppliers for the EU-27, as can be seen from column 3. Given the small size of many Eastern European economies, only four out of twelve make it into the list of the top 30. Nevertheless, all these countries have improved their relative position over time and some countries like Poland and the Czech Republic have experienced one of the largest increases in terms of exported products among all the other countries, ranked 2 and 3 in the absolute increase in the number of varieties. This underlines the growing importance of Eastern European economies as a source of new products and varieties. On the other hand high-income nonEuropean Union members like the United States, Japan, Norway and Switzerland have become less important as a suppliers of new products.

\footnotetext{
${ }^{7}$ Intensive margins of trade mean that more products of the same category have been traded. This is in line with the findings of Besedes and Prusa (2007) for high-income countries.
} 
Table 3: Ranking in terms of the number of goods imported by the EU-27 member states

\begin{tabular}{lrrr|rrr}
\hline \hline & \multicolumn{3}{c|}{ ranks variety } & \multicolumn{3}{c}{ ranks value } \\
& 1999 & 2008 & increase & 1999 & 2008 & increase \\
\hline & $(1)$ & $(2)$ & $(3)$ & $(4)$ & $(5)$ & $(6)$ \\
\hline Germany & 1 & 1 & 10 & 1 & 1 & 1 \\
Italy & 2 & 2 & 12 & 6 & 6 & 7 \\
France & 3 & 3 & 25 & 2 & 3 & 6 \\
United Kingdom & 4 & 5 & 170 & 5 & 7 & 12 \\
Netherlands & 5 & 4 & 7 & 4 & 2 & 3 \\
USA & 6 & 8 & 169 & 3 & 8 & 24 \\
Belgium & 7 & 6 & 5 & 7 & 5 & 5 \\
Spain & 8 & 9 & 8 & 8 & 10 & 8 \\
Austria & 9 & 10 & 6 & 14 & 16 & 13 \\
Switzerland & 10 & 14 & 171 & 10 & 15 & 18 \\
Sweden & 11 & 11 & 17 & 12 & 11 & 14 \\
Denmark & 12 & 12 & 19 & 15 & 21 & 22 \\
China & 13 & 7 & 1 & 11 & 4 & 2 \\
Japan & 14 & 17 & 172 & 9 & 13 & 38 \\
Czech Republic & 15 & 15 & 3 & 22 & 17 & 11 \\
Taiwan & 16 & 20 & 168 & 19 & 29 & 52 \\
Poland & 17 & 13 & 2 & 20 & 14 & 9 \\
Finland & 18 & 19 & 24 & 18 & 23 & 28 \\
Hungary & 19 & 18 & 9 & 23 & 19 & 15 \\
Turkey & 20 & 16 & 4 & 25 & 20 & 16 \\
Korea (South) & 21 & 23 & 42 & 21 & 22 & 20 \\
Norway & 22 & 27 & 167 & 16 & 12 & 10 \\
Portugal & 23 & 24 & 39 & 24 & 28 & 37 \\
Ireland & 24 & 26 & 48 & 13 & 18 & 25 \\
Canada & 25 & 25 & 41 & 27 & 32 & 44 \\
India & 26 & 21 & 13 & 30 & 27 & 23 \\
Hong Kong & 27 & 28 & 35 & 33 & 48 & 73 \\
Greece & 28 & 29 & 22 & 38 & 51 & 60 \\
Thailand & 29 & 30 & 30 & 32 & 37 & 43 \\
Slovakia & 30 & 22 & 11 & 35 & 25 & 19 \\
\hline \hline & & & & & & \\
\hline
\end{tabular}

Notes: The ranking is based on the aggregated number of products exported by a single country to all European Union member states at the HS-8 level. The total number of trading partners is 189 .

\subsection{Analysis of Disaggregated Trade Flows}

So far our analysis has relied on aggregated data on the European level. We now focus on disaggregated country data to provide a more detailed picture of the development of imported varieties for each single member state. Given our assumption that products are differentiated across countries, there are two potential sources for new varieties. First, an entirely new goods category is imported. Second, the number of supplying countries of an individual good is increasing. Therefore, Table 4 includes some descriptive statistics regarding the number of imported product categories and the average trading partners for a single product. Larger and high-income countries import a larger set of goods from a more diverse set of countries. This is in line with the New Trade Theory first outlined by Krugman $(1979,1980)$ and what other empirical studies by Hummels and Klenow (2002) and Broda and Weinstein (2004) have found.

From columns 1 and 2 we can see that the total number of imported product categories is relatively constant over time for all the countries: while for most of the "old" member states the number of imported goods decreases slightly, modest increases can be observed for some of the "new" member states. Hence, the importing of new products has played a role in extending the set of available products for consumers in some of these countries. Also note that many of the old member states already imported in nearly all the product categories at the HS- 8 level in $1999 .{ }^{8}$ At the same time the average number of supplying countries of each individual good has increased for all the countries, except for Hungary and Malta (columns 3 and 4). The increase has been largest for the "small old" and the "new" member states. Consequently, the overall variety growth can be mainly attributed to the effect of an increased number of trading partners for a specific product category. Taken together, this translates into an overall

\footnotetext{
${ }^{8}$ This limits the possibility of an increase in the number of varieties via the new goods dimension. "New" goods may essentially be classified in already existing goods categories, resulting in an potential underestimation of variety growth.
} 
increase of imported varieties for all the countries except Cyprus, Hungary, and Malta, as can be seen from columns 5 and 6 . This is in line with what our previous analysis has already shown. The increase in imported varieties is largest for the "new", modest for the "small old", and relatively small for the "big four" member states. Although, there are similar numbers of new and disappearing varieties for most countries (columns 7 and 8), from column 9 and 10 we can see that the value of new varieties is much higher than the value of disappearing ones, especially for the "new" member states. This indicates that new varieties have played a more important role than disappearing ones in the consumer budget decision.

Table 4: Variety of EU-27 imports from worldwide trading partners (1999-2008)

\begin{tabular}{|c|c|c|c|c|c|c|c|c|c|c|}
\hline & \multirow{2}{*}{\multicolumn{2}{|c|}{$\begin{array}{l}\text { Total no. } \\
\text { of goods }\end{array}$}} & \multirow{2}{*}{\multicolumn{2}{|c|}{$\begin{array}{l}\text { Mean no. } \\
\text { of countries }\end{array}$}} & \multirow{2}{*}{\multicolumn{2}{|c|}{$\begin{array}{l}\text { Total no. } \\
\text { of varieties }\end{array}$}} & \multicolumn{2}{|c|}{ Varieties } & \multicolumn{2}{|c|}{ Value (mil. euro) } \\
\hline & & & & & & & disapp. & new. & disapp. & new. \\
\hline & 1999 & 2008 & 1999 & 2008 & 1999 & 2008 & 1999 & 2008 & 1999 & 2008 \\
\hline & (1) & (2) & $\begin{array}{l}(3) \\
\end{array}$ & (4) & (5) & (6) & (7) & (8) & (9) & (10) \\
\hline France & 9,969 & 9,368 & 11.34 & 13.11 & 113,043 & 122,795 & 34,266 & 33,604 & 29,157 & 36,329 \\
\hline Germany & 9,722 & 8,912 & 13.91 & 15.87 & 135,216 & 141,464 & 40,000 & 39,536 & 16,262 & 30,363 \\
\hline Great Britain & 9,562 & 9,090 & 11.38 & 13.32 & 108,857 & 121,124 & 33,163 & 33,407 & 36,134 & 58,766 \\
\hline Italy & 9,675 & 9,072 & 10.30 & 12.26 & 99,628 & 111,214 & 29,288 & 30,331 & 14,766 & 23,395 \\
\hline Austria & 9,292 & 8,791 & 7.61 & 9.94 & 70,742 & 87,409 & 21,393 & 24,351 & 26,254 & 34,824 \\
\hline Belgium & 9,685 & 9,073 & 8.35 & 11.09 & 80,894 & 100,596 & 23,669 & 27,578 & 4,953 & 6,224 \\
\hline Denmark & 8,330 & 8,384 & 6.52 & 8.86 & 54,325 & 74,268 & 16,220 & 21,021 & 3,639 & 6,048 \\
\hline Finland & 8,287 & 7,895 & 6.62 & 8.15 & 54,894 & 64,352 & 16,635 & 18,502 & 2,595 & 3,117 \\
\hline Greece & 8,255 & 8,022 & 5.69 & 7.10 & 46,948 & 56,991 & 13,604 & 15,425 & 2,846 & 4,368 \\
\hline Ireland & 8,375 & 7,947 & 4.30 & 5.57 & 36,046 & 44,271 & 11,621 & 12,354 & 8,699 & 22,122 \\
\hline Luxemburg & 7,862 & 7,834 & 3.63 & 4.16 & 28,578 & 32,575 & 8,655 & 9,494 & 10,500 & 20,450 \\
\hline Netherlands & 9,238 & 8,867 & 9.91 & 11.78 & 91,578 & 104,446 & 27,724 & 30,939 & 814 & 2,411 \\
\hline Portugal & 8,529 & 8,429 & 6.07 & 6.93 & 51,779 & 58,399 & 15,385 & 16,773 & 5,674 & 9,895 \\
\hline Spain & 9,345 & 8,931 & 7.72 & 9.92 & 72,127 & 88,585 & 21,237 & 23,916 & 2,829 & 4,894 \\
\hline Sweden & 8,855 & 8,458 & 8.48 & 9.95 & 75,065 & 84,175 & 22,970 & 23,986 & 5,233 & 9,678 \\
\hline Bulgaria & 6,6 & 7,509 & 5.15 & 7.16 & 34,229 & & 10,802 & 17,557 & 339 & 386 \\
\hline Cyprus & 5,951 & 5,932 & 5.12 & 5.13 & 30,477 & 30,407 & 9,900 & 9,586 & 272 & 975 \\
\hline Czech Republic & 8,848 & 8,598 & 8.54 & 9.55 & 75,568 & 82,106 & 22,884 & 23,761 & 193 & 942 \\
\hline Estonia & 6,779 & 7,054 & 4.90 & 6.44 & 33,220 & 45,404 & 10,388 & 14,148 & 231 & 1,317 \\
\hline Hungary & 7,049 & 6,805 & 9.46 & 9.37 & 66,689 & 63,757 & 21,768 & 20,205 & 3,037 & 10,944 \\
\hline Latvia & 6,274 & 7,228 & 4.63 & 6.76 & 29,041 & 48,870 & 8,599 & 15,837 & 1,994 & 9,100 \\
\hline Lithunia & 6,654 & 7,378 & 5.46 & 7.47 & 36,343 & 55,099 & 10,677 & 17,255 & 714 & 4,364 \\
\hline Malta & 5,517 & 5,258 & 3.88 & 3.58 & 21,418 & 18,829 & 7,625 & 6,124 & 2,237 & 7,465 \\
\hline Poland & 8,766 & 8,653 & 9.67 & 10.41 & 84,736 & 90,107 & 25,518 & 26,063 & 595 & 3,948 \\
\hline Romanic & 7,446 & 8,243 & 6.50 & 9.30 & 48,421 & 76,646 & 14,619 & 23,486 & 249 & 1,483 \\
\hline Slovakia & 7,650 & 7,952 & 6.03 & 7.03 & 46,131 & 55,894 & 14,142 & 17,166 & 686 & 2,074 \\
\hline Slovenia & 7,785 & 8,059 & 6.74 & 7.04 & 52,464 & 56,771 & 16,002 & 17,021 & 217 & 695 \\
\hline
\end{tabular}

Notes: A good is defined after the HS-8 classification and a variety is defined as a good from a particular country. For convenience we ordered the table according to our definition of our three subgroups of European Union member states.

In Tables 5 and 6 we again split up the data by European Union internal and external imports to evaluate further the different sources of traded varieties for each country. In Table 5 , specifics about the imports stemming from other European trading partners are depicted, whereas in Table 6 the imports from non-European countries are displayed. Comparing the first two columns of Table 5 with those of Table 6 we can see that the number of imported product categories from the rest of the world compared with internal imported varieties is lower for all the countries. Especially, large and "old" member states already import nearly all the classified product categories from the EU-27 at the beginning of our period. For example, France imported 9,860 out of 10,428 product categories in 1999. On the other hand some "new" member states have experienced a strong increase in imported product categories stemming from other European member states. A case in point is Latvia, which only imported in 5,892 product categories in 1999 but in 7,007 categories in 2008. Similar to the number of imported goods, the average number of supplying countries as displayed in columns 3 and 4 per good is higher for internally traded products for all the countries, except for the Netherlands. This is interesting, given the small number of potential trading partners within the European Union. While for the "big four" the difference 
between internal and external average trading partners is relatively small, it is high for all the other European Union members. In 2008, Germany imported each good on average from 8.79 European Union members and from 8.55 non-European members, while for the Czech Republic the average was 7.04 for internally but only 4.10 for externally imported goods.

Table 5: Variety of EU-27 imports from European Union internal trading partners (1999-2008)

\begin{tabular}{|c|c|c|c|c|c|c|c|c|c|c|}
\hline & \multirow{2}{*}{\multicolumn{2}{|c|}{$\begin{array}{l}\text { Total no. } \\
\text { of goods }\end{array}$}} & \multirow{2}{*}{\multicolumn{2}{|c|}{$\begin{array}{c}\text { Mean no. } \\
\text { of countries }\end{array}$}} & \multirow{2}{*}{\multicolumn{2}{|c|}{$\begin{array}{l}\text { Total no. } \\
\text { of varieties }\end{array}$}} & \multicolumn{2}{|c|}{ Varieties } & \multicolumn{2}{|c|}{ "Value (mil. euro) } \\
\hline & & & & & & & disapp. & new. & disapp. & new. \\
\hline & 1999 & 2008 & 1999 & 2008 & 1999 & 2008 & 1999 & 2008 & 19 & 2008 \\
\hline & (1) & $(2)$ & $(3)$ & (4) & (5) & (6) & (7) & (8) & (9) & (10) \\
\hline France & 9,860 & 9,298 & 7.10 & 8.28 & 69,998 & 77,000 & 20,645 & 20,441 & 19,150 & 25,054 \\
\hline Germany & 9,360 & 8,473 & 8.13 & 8.79 & 76,064 & 74,510 & 22,395 & 19,834 & 8,329 & 13,307 \\
\hline Great Britain & 9,155 & 8,790 & 6.21 & 7.29 & 56,896 & 63,938 & 17,173 & 17,531 & 23,220 & 37,781 \\
\hline Italy & 9,544 & 8,943 & 6.48 & 7.26 & 61,881 & 64,958 & 18,152 & 17,398 & 10,341 & 14,632 \\
\hline Austria & 9,192 & 8,702 & 5.40 & 6.25 & 49,598 & 54,359 & 14,855 & 14,820 & 14,930 & 20,488 \\
\hline Belgium & 9,553 & 8,951 & 5.90 & 7.08 & 56,327 & 63,332 & 16,523 & 17,127 & 2,391 & 3,432 \\
\hline Denmark & 7,997 & 8,035 & 4.71 & 5.65 & 37,705 & 45,414 & 11,248 & 12,918 & 2,739 & 4,630 \\
\hline Finland & 8,009 & 7,681 & 4.82 & 5.71 & 38,601 & 43,823 & 11,594 & 12,367 & 1,616 & 2,280 , \\
\hline Greece & 8,054 & 7,825 & 4.23 & 5.21 & 34,054 & 40,803 & 10,031 & 11,019 & 2,397 & 3,546 \\
\hline Ireland & 8,133 & 7,702 & 2.90 & 3.59 & 23,585 & 27,682 & 7,526 & 7,661 & 6,558 & 14,311 \\
\hline Luxem & 7,814 & 7,810 & 3.28 & 3.75 & 25,618 & 29,325 & 7,659 & 8,379 & 7,888 & 14,814 \\
\hline Netherlands & 8,896 & 8,530 & 5.68 & 6.20 & 50,490 & 52,920 & 15,388 & 15,296 & 579 & 1,197 \\
\hline Portugal & 8,333 & 8,328 & 4.52 & 4.91 & 37,672 & 40,903 & 11,119 & 11,641 & 4,112 & 7,488 \\
\hline Spain & 9,095 & 8,757 & 5.10 & 6.42 & 46,427 & 56,188 & 13,684 & 15,187 & 1,875 & 2,941 \\
\hline Sweden & 8,391 & 8,129 & 5.44 & 6.09 & 45,626 & 49,511 & 13,877 & 13,951 & 4,266 & 7,789 \\
\hline Bulgaria & 6,045 & 7,164 & 3.64 & 5.15 & 21,984 & 36,892 & 6,836 & 12,728 & 216 & 293 \\
\hline Cyprus & 5,436 & 5,500 & 3.43 & 3.60 & 18,625 & 19,781 & 6,296 & 6,591 & 184 & 745 \\
\hline Czech Republic & 8,564 & 8,505 & 5.73 & 7.04 & 49,073 & 59,842 & 14,714 & 17,257 & 141 & 700 \\
\hline Estonia & 6,289 & 6,834 & 3.73 & 5.14 & 23,459 & 35,112 & 7,277 & 11,351 & 158 & 1,027 \\
\hline Hungary & 6,862 & 6,719 & 6.15 & 6.50 & 42,219 & 43,705 & 13,687 & 13,812 & 2,119 & 8,796 \\
\hline Latvia & 5,892 & 7,007 & 3.89 & 5.40 & 22,891 & 37,806 & 6,767 & 12,671 & 1,602 & 7,281 \\
\hline Lithunia & 5,980 & 7,152 & 4.05 & 5.88 & 24,244 & 42,089 & 6,866 & 14,086 & 578 & 3,216 \\
\hline Malta & 5,072 & 4,863 & 2.64 & 2.68 & 13,409 & 13,019 & 4,988 & 4,491 & 1,615 & 4,570 \\
\hline Poland & 8,371 & 8,528 & 6.25 & 7.28 & 52,296 & 62,044 & 15,438 & 17,950 & 438 & 3,045 \\
\hline Romani & 6,995 & 8,110 & 4.69 & 6.72 & 32,800 & 54,488 & 9,751 & 17,422 & 177 & 1,154 \\
\hline Slovakia & 7,336 & 7,876 & 4.49 & 5.40 & 32,927 & 42,512 & 9,897 & 13,456 & 517 & 1,470 \\
\hline Slovenia & 7,488 & 7,927 & 4.41 & 5.18 & 33,011 & 41,092 & 10,027 & 12,585 & 137 & 398 \\
\hline
\end{tabular}

Note: A good is defined after the HS-8 classification and a variety is defined as a good from a particular country. For convenience we ordered the table according to our definition of our three subgroups of European Union member states.

This fact stresses the importance of internal European Union trade partners as a source of varieties for smaller members of the European Union. Over time, the mean number of supplying countries for each individual good has increased for all the countries, as well from internal and external trading partners. Here, two points are striking: for the "small old" member states the average supplying country has grown relatively strongly from non-European Union members, while for the "new" members the average trading partners increased with other European Union members. Taking the effect of imported product categories and new trading partners together we obtain the following results for imported varieties (columns 5 and 6). First, for the "big four" economies neither the EU-27 nor the rest of the world has been an important source of newly traded products or varieties over the last decade. Second, the small member states have gained access to new varieties via the establishment of new trade linkages with new trading partners at the global level, while the European Union and imports of entirely new product categories only had a minor effect. Finally, "new" member states have benefited from both the import of new product categories and new trading partners within the European Union, but less from trade with countries outside the European Union. Regarding the number of new and disappearing varieties, they are roughly equal in most cases for internal as well as for external imports. Again, the absolute value of newly imported varieties is strictly higher compared with disappearing varieties. 
Table 6: Variety of EU-27 imports from non-European Union trading partners (1999-2008)

\begin{tabular}{|c|c|c|c|c|c|c|c|c|c|c|}
\hline & \multirow{2}{*}{\multicolumn{2}{|c|}{$\begin{array}{l}\text { Total no. } \\
\text { of goods }\end{array}$}} & \multirow{2}{*}{\multicolumn{2}{|c|}{$\begin{array}{c}\text { Mean no. } \\
\text { of countries }\end{array}$}} & \multirow{2}{*}{\multicolumn{2}{|c|}{$\begin{array}{l}\text { Total no. } \\
\text { of varieties }\end{array}$}} & \multicolumn{2}{|c|}{ Varieties } & \multicolumn{2}{|c|}{ Value (mil. euro) } \\
\hline & & & & & & & disapp. & new & disapp. & new \\
\hline & 1999 & 2008 & 1999 & 2008 & 1999 & 2008 & 1999 & 2008 & 1999 & 2008 \\
\hline & (1) & (2) & (3) & (4) & $(5)$ & (6) & (7) & (8) & (9) & (10) \\
\hline France & 7,707 & 7,414 & 5.60 & 6.19 & 43,170 & 45,905 & 14,356 & 14,151 & 10,158 & 11,599 \\
\hline Germany & 8,393 & 7,849 & 7.07 & 8.55 & 59,298 & 67,078 & 18,629 & 20,459 & 8,035 & 17,449 \\
\hline Great Britain & 8,184 & 7,853 & 6.36 & 7.27 & 52,037 & 57,281 & 16,803 & 17,018 & 13,008 & 21,227 \\
\hline Italy & 7,260 & 7,424 & 5.20 & 6.23 & 37,773 & 46,274 & 11,664 & 14,288 & 4,502 & 9,016 \\
\hline Austria & 6,047 & 6,233 & 3.50 & 5.31 & 21,163 & 33,119 & 7,154 & 10,941 & 11,512 & 14,996 \\
\hline Belgium & 6,637 & 6,959 & 3.71 & 5.36 & 24,607 & 37,302 & 7,758 & 12,135 & 2,626 & 2,954 \\
\hline Denmark & 5,295 & 6,152 & 3.14 & 4.70 & 16,630 & 28,888 & 5,555 & 10,352 & 942 & 1,744 \\
\hline Finland & 5,237 & 5,146 & 3.11 & 4.01 & 16,302 & 20,624 & 5,998 & 7,439 & 1,048 & 1,035 \\
\hline Greece & 4,413 & 4,931 & 2.93 & 3.29 & 12,919 & 16,222 & 4,379 & 6,054 & 542 & 970 \\
\hline Ireland & 4,542 & 4,740 & 2.74 & 3.50 & 12,467 & 16,605 & 4,975 & 6,288 & 2,358 & 8,224 \\
\hline Luxemburg & 1,729 & 1,575 & 1.72 & 2.06 & 2,980 & 3,252 & 1,711 & 1,734 & 2,766 & 5,943 \\
\hline Netherlands & 7,270 & 7,293 & 5.66 & 7.08 & 41,128 & 51,625 & 13,209 & 17,121 & 270 & 1,242 \\
\hline Portugal & 4,684 & 4,860 & 3.02 & 3.61 & 14,134 & 17,554 & 5,145 & 6,533 & 1,601 & 2,611 \\
\hline Spain & 6,595 & 6,852 & 3.94 & 4.78 & 25,998 & 32,746 & 8,240 & 10,405 & 1,035 & 2,037 \\
\hline Sweden & 6,866 & 6,620 & 4.29 & 5.24 & 29,465 & 34,701 & 9,958 & 11,195 & 1,008 & 1,975 \\
\hline Bulgaria & 4,440 & 5,243 & 2.76 & 3.22 & 12,248 & 16,890 & 4,655 & 7,168 & 142 & 114 \\
\hline Cyprus & 3,741 & 3,573 & 3.17 & 2.98 & 11,854 & 10,632 & 4,770 & 4,121 & 107 & 270 \\
\hline Czech Republic & 6,231 & 5,440 & 4.26 & 4.10 & 26,533 & 22,305 & 9,781 & 7,655 & 62 & 305 \\
\hline Estonia & 4,015 & 3,758 & 2.43 & 2.74 & 9,765 & 10,294 & 4,413 & 4,286 & 96 & 376 \\
\hline Hungary & 5,518 & 4,779 & 4.44 & 4.20 & 24,485 & 20,073 & 9,453 & 7,135 & 1,033 & 2,476 \\
\hline Latvia & 3,180 & 4,024 & 1.93 & 2.76 & 6,150 & 11,095 & 2,478 & 5,257 & 450 & 1,936 \\
\hline Lithunia & 4,409 & 4,300 & 2.74 & 3.03 & 12,099 & 13,014 & 5,025 & 5,209 & 175 & 1,293 \\
\hline Malta & 3,105 & 2,597 & 2.58 & 2.24 & 8,009 & 5,823 & 3,908 & 2,494 & 657 & 2,984 \\
\hline Poland & 6,717 & 6,135 & 4.84 & 4.59 & 32,490 & 28,158 & 11,437 & 9,547 & 187 & 1,119 \\
\hline Romania & 4,894 & 5,526 & 3.20 & 4.05 & 15,673 & 22,359 & 5,626 & 8,692 & 92 & 498 \\
\hline Slovakia & 4,423 & 4,121 & 2.99 & 3.25 & 13,216 & 13,393 & 5,478 & 5,141 & 204 & 676 \\
\hline Slovenia & 5,303 & 4,822 & 3.67 & 3.26 & 19,470 & 15,714 & 7,498 & 5,632 & 95 & 333 \\
\hline
\end{tabular}

Note: A good is defined after the HS-8 classification and a variety is defined as a good from a particular country. For convenience we ordered the table according to our definition of our three subgroups of European Union member states.

In section 4 we provide a more detailed discussion and interpretation of the possible economic forces that are driving these results.

\section{Empirical Strategy}

In this section we briefly review the methodology used to determine the gains from variety for the consumers. It is mainly developed by Feenstra (1994) and by Broda and Weinstein (2006).

\subsection{The Variety Gains from Trade}

We follow Feenstra (1994) to derive an exact price index for a CES utility function of a single good with a constant number of varieties. This index is then extended by allowing for new and disappearing varieties. Finally, we show how to construct a aggregate import price index based on the contribution of Broda and Weinstein (2006). We start with a simple CES utility function with the following functional form for a single imported good. To define a variety of a good we assume that imports of one good $g$ are treated as differentiated across countries of supply, $c$ :

$$
M_{g, t}=\left(\sum_{c \in C} d_{g, c, t} M_{g, c, t}^{1-\sigma_{g}}\right)^{\frac{1}{\left(1-\sigma_{g}\right)}} ; \sigma_{g}>1,
$$

where $C$ denotes the set of available countries and hence of all potentially available varieties. $M_{g, c, t}$ is the subutility derived from the imported variety $c$ of good $g$ in period $t$ and $d_{g, c, t}>0$ is the 
corresponding taste or quality parameter. The elasticity of substitution among varieties is given by $\sigma_{g}$ and is assumed to be larger than one. Using standard cost minimization gives us the minimum unit-cost function.

$$
\phi_{g, t}\left(I_{g, t}, \vec{d}_{g, t}\right)=\left(\sum_{c \in I_{g, t}} d_{g, c, t}\left(p_{g, c, t}\right)^{1-\sigma_{g}}\right)^{\frac{1}{1-\sigma_{g}}}
$$

where $p_{g, c, t}$ is the price of variety $c$ of good $g$ in period $t$ and $\vec{d}_{c, t}$ is the vector of taste or quality parameters. $I_{g, t} \subset C$ is the subset of varieties of good $g$ imported at time $t$. Suppose the set of available product varieties $I_{g, t}$ in period $t$ and $t-1$ is identical, the taste parameters $\vec{d}_{c, t}$ are also constant over time and $\vec{x}_{t}$ and $\vec{x}_{t-1}$ are the cost-minimizing consumption bundle vectors for the varieties of one good for given the price vectors. In this case Diewert (1976) defines an exact price index as a ratio of the minimum cost functions

$$
P_{g}\left(\vec{p}_{g, t}, \vec{p}_{g, t-1}, \vec{x}_{g, t}, \vec{x}_{g, t-1}, I_{g}\right)=\frac{\phi_{g, t}\left(I_{g}, \vec{d}_{g}\right)}{\phi_{g, t-1}\left(I_{g}, \vec{d}_{g}\right)}
$$

where the price index does not depend on the unknown taste parameters $\vec{d}_{c, t}$. Sato (1976) and Vartia (1976) have derived the exact price index for our CES unit-cost function. It can be written as the geometric mean of the individual price changes

$$
P_{g}\left(\vec{p}_{g, t}, \vec{p}_{g, t-1}, \vec{x}_{g, t}, \vec{x}_{g, t-1}, I_{g}\right)=\prod_{c \in I_{g}}\left(\frac{p_{g, c, t}}{p_{g, c, t-1}}\right)^{w_{g, c, t}}
$$

where the weights are calculated using the expenditure shares in the two periods:

$$
\begin{gathered}
w_{g, c, t}=\frac{\left(\frac{s_{g, c, t}-s_{g, c, t-1}}{\ln s_{g, c, t}-\ln s_{g, c, t-1}}\right)}{\sum_{c \in I_{g}}\left(\frac{s_{g, c, t}-s_{g, c, t-1}}{\ln s_{g, c, t}-\ln s_{g, c, t-1}}\right)} \\
s_{g, c, t}=\frac{p_{g, c, t} x_{g, c, t}}{\sum_{c \epsilon I_{g}} p_{g, c, t} x_{g, c, t}}
\end{gathered}
$$

So far we have assumed that all varieties of one good are available in both periods to calculate the exact price index. As our data also include new and disappearing varieties we use the price index developed by Feenstra (1994) which allows to incorporate new and disappearing product varieties given by the following proposition.

Proposition: For every good $g$, if $d_{g, c, t}=d_{g, c, t-1}$ for $c \in I_{g}=\left(\left(I_{g, t} \cap C_{g, t-1}\right) ; \quad I_{G} \neq \emptyset\right.$, then the exact price index for good $g$ with change in varieties is given by

$$
\begin{aligned}
\Pi_{g}\left(\vec{p}_{g, t}, \vec{p}_{g, t-1}, \vec{x}_{g, t}, \vec{x}_{g, t-1}, I_{g}\right) & =\frac{\phi_{g, t}\left(I_{g, t}, \vec{d}_{g}\right)}{\phi_{g, t}\left(I_{g, t-1}, \vec{d}_{g}\right)} \\
& =P_{g}\left(\vec{p}_{g, t}, \vec{p}_{g, t-1}, \vec{x}_{g, t}, \vec{x}_{g, t-1}, I_{g}\right)\left(\frac{\lambda_{g, t}}{\lambda_{g, t-1}}\right)^{\frac{1}{\sigma_{g}-1}},
\end{aligned}
$$

where

$$
\lambda_{g, r}=\frac{\sum_{c \epsilon I_{g}} p_{g, c, r} x_{g, c, r}}{\sum_{c \in I_{g, r}} p_{g, c, r} x_{g, c, r}} ; r=t, t-1 .
$$

The idea of the Feenstra (1994) index is to correct the conventional price index $P_{g}$ by multiplying it with an additional term which measures the influence of new and disappearing varieties and is called the lambda or Feenstra ratio. If $r=t$, the numerator of this term quantifies the impact of newly available varieties as $\lambda_{g, t}$ is the ratio of expenditures on varieties available in both periods relative to the entire set of varieties available in period $t$. Hence, $\lambda_{g, t}$ decreases when new varieties appear and so does the price index. On the other hand the denominator of the lambda ratio captures the impact of disappearing 
varieties. They lower $\lambda_{g, t-1}$ and the index is increased. Secondly, the exact price index depends on the elasticity of substitution between varieties. If we observe a high elasticity of substitution, the additional term $\left(\frac{\lambda_{t}}{\lambda_{t}-1}\right)^{\frac{1}{\sigma-1}}$ will approach unity and the influence on the price index is small. From an economic point of view this is intuitive, since new and disappearing products will only have a minor influence on the welfare of consumers if there exist close substitutes, i.e. if the varieties are homogeneous. Having derived the exact price index for one good, we can now aggregate the imported goods to an aggregate import price index as in Broda and Weinstein (2006). This is done by building a geometric mean of the price indices. The aggregate import price index is then given by

$$
\begin{aligned}
\Pi\left(\vec{p}_{t}, \vec{p}_{t-1}, \vec{x}_{t}, \vec{x}_{t-1}, I\right) & =\left[P_{g}(.) \prod_{g \in G}\left(\frac{\lambda_{g, t}}{\lambda_{g, t-1}}\right)^{\left(1 / \sigma_{g}-1\right)}\right]^{w_{g, t}}, \\
& =C I P I(I) \prod_{g \in G}\left(\frac{\lambda_{g, t}}{\lambda_{g, t-1}}\right)^{w_{g, t} /\left(\sigma_{g}-1\right)},
\end{aligned}
$$

where the weights $w_{g, t}$ are defined as above. Equation (9) shows that the aggregate exact import price index is the product of a conventional import price index, $C I P I(I)$, and the aggregated lambda ratios. Consequently, the following measure, called endpoint ratio (EPR) can be used as an indicator of the upward bias of a conventional price index compared to the corrected price index. It is the ratio of the corrected import price index and the conventional import price index:

$$
E P R=\frac{\Pi^{M}}{C I P I(I)}=\prod_{g}\left(\frac{\lambda_{g t}}{\lambda_{g t-1}}\right)^{w_{g t} /\left(\sigma_{g}-1\right)} .
$$

Using a simple Krugman (1980) structure of the economy, the inverse of the endpoint ratio can be weighted by the share of imports on the GDP to get the gains from variety:

$$
G F V=\left[\frac{1}{E P R}\right]^{w_{t}^{M}}-1=\left[\prod_{g}\left(\frac{\lambda_{g t}}{\lambda_{g t-1}}\right)^{-w_{g t} /\left(\sigma_{g}-1\right)}\right]^{w_{t}^{M}}-1
$$

where $w_{t}^{M}$ is the import share.

\subsection{Stochastic Specification}

In order to compute the exact import price index we have to estimate the elasticity of substitution between varieties of each good. Therefore we briefly review the estimator developed by Feenstra (1994). Given our utility function (1), we can derive the import demand equation for a single variety using expenditure shares $s$ as defined above. ${ }^{9}$ Taking logs and first differences results in:

$$
\Delta \ln s_{g, c, t}=\varphi_{g, t}-\left(\sigma_{g}-1\right) \Delta \ln p_{g, c, t}+\varepsilon_{g, c, t},
$$

where $\sigma_{g}$ is equal across countries, $\varphi_{g, t}=\left(\sigma_{g}-1\right) \ln \left[\phi g, t^{M}\left(d_{t}\right) / \phi_{g, t-1}^{M}\left(d_{t-1}\right)\right]$ is a random effect since $d_{t}$ is unobserved and $\varepsilon_{g, c, t}=\Delta \ln d_{g, c, t}$. The export supply equation in logs and first differences is specified by

$$
\Delta \ln p_{g, c, t}=\psi_{g, t}+\frac{\omega_{g}}{1+\omega_{g}} \Delta \ln s_{g, c, t}+\delta_{g, c, t} .
$$

where $\omega_{g} \geq 0$ is the good specific inverse supply elasticity ${ }^{10}$ (assumed to be constant across countries) and $\delta_{g, c, t}$ is an error term. To identify the elasticity of substitution we have to assume that the the error terms between the demand and supply curve $\left(\varepsilon_{g, c, t}, \delta_{g, c, t}\right)$ are uncorrelated after controlling

\footnotetext{
${ }^{9}$ Using shares helps to avoid the problems of measurement error of unit-value indices as pointed out by Kemp (1962)

${ }^{10}$ If $\omega_{g}=0$ we get the special case of a horizontal supply curve
} 
for good and time specific effects. To take advantage of this assumption we first eliminate the random terms $\varphi_{g, t}$ and $\psi_{g, t}$ from equations (12) and (13) by taking differences relative to a reference country $k$ :

$$
\begin{aligned}
& \Delta^{k} e_{g, c, t}=-\left(\sigma_{g}-1\right) \Delta^{k} \ln p_{g, c, t}+\varepsilon_{g, c, t}^{k} \\
& \Delta^{k} \ln p_{g, c, t}=\frac{\omega_{g}}{1+\omega_{g}} \Delta^{k} \ln s_{g, c, t}+\delta_{g, c, t}^{k},
\end{aligned}
$$

where $\Delta^{k} K_{g, c, t}=\Delta K_{g, c, t}-\Delta K_{g, k, t}$ for $K=(\ln p, \ln s), \varepsilon_{g, c, t}^{r}=\varepsilon_{g, c, t}-\varepsilon_{g, r, t}$ and $\delta_{g, c, t}^{r}=\delta_{g, c, t}-$ $\delta_{g, r, t}$. We can now use the assumption of the independent error terms to multiply (14) and (15) and dividing by $\left(1-\rho_{g}\right)\left(\sigma_{g}-1\right)$ to obtain

$$
\begin{gathered}
\left(\Delta^{k} \ln p_{g, c, t}\right)^{2}=\theta_{1, g}\left(\Delta^{k} \ln s_{g, c, t}\right)^{2}+\theta_{2, g}\left(\Delta^{k} \ln p_{g, c, t} \Delta^{k} \ln s_{g, c, t}\right)+u_{g, c, t} \text { or } \\
Y_{g, c, t}=\theta_{1, g} X_{1, g, c, t}+\theta_{2, g} X_{2, g, c, t}+u_{g, c, t},
\end{gathered}
$$

with obvious definitions of $\theta_{1, g}$ and $\theta_{2, g}$. Since the error term $u_{g, c, t}$ is correlated with the prices and expenditure shares in $X_{1, g, c, t}$ and $X_{2, g, c, t}$, we do not get a consistent estimator for $\theta_{1, g}$ and $\theta_{2, g}$. However, Feenstra (1994) shows how to exploit the panel structure of the data to get a consistent estimator by averaging (17) over all $t$. Hence, we can use the GMM estimator developed by Hanson (1998) to run a regression on the transformed equation of (17) to estimate $\theta_{1, g}$ and $\theta_{2, g}$ consistently.

$$
\bar{Y}_{g, c, t}=\theta_{1, g} \bar{X}_{1, g, c, t}+\theta_{2, g} \bar{X}_{2, g, c, t}+\bar{u}_{g, c, t}
$$

where upper bars on variables denote sample means over $t .^{11}$ Once, we have consistent estimators of $\theta_{1, g}$ and $\theta_{2, g}$ we can calculate the elasticity of substitution $\sigma_{g}$ :

As long as $\theta_{1, g}>0, \sigma_{g}$ can be estimated as

$$
\begin{aligned}
& \text { a) if } \widehat{\theta}_{2, g}>0 \quad \text { then } \widehat{\rho}_{g}=\frac{1}{2}+\left(\frac{1}{4}-\frac{1}{4\left(\widehat{\theta}_{2, g}^{2} / \widehat{\theta}_{1, g}\right)}\right)^{1 / 2}, \\
& \text { b) if } \widehat{\theta}_{2, g}<0 \quad \text { then } \quad \hat{\rho}_{g}=\frac{1}{2}-\left(\frac{1}{4}-\frac{1}{4\left(\widehat{\theta}_{2, g}^{2} / \widehat{\theta}_{1, g}\right)}\right)^{1 / 2}
\end{aligned}
$$

and in either case,

$$
\widehat{\sigma}_{g}=1+\left(\frac{2 \widehat{\rho}_{g}-1}{1-\widehat{p}_{g}}\right) \frac{1}{\widehat{\theta}_{g 2}} .
$$

\section{Results}

In this section we discuss the results of our estimation of the consumer gains from an increased imported product variety. Furthermore, we show where these gains come from geographically and provide some robustness measures for our results.

\subsection{The Gains from Variety in the Countries of the European Union}

The final aim of our empirical analysis is to evaluate equation (11), which quantifies the variety gains from trade with respect to GDP. In a first step we use equation (7) to calculate the lambda ratios for each

\footnotetext{
${ }^{11}$ Feenstra (1994) points out that $\theta_{1, g}$ and $\theta_{2}, g$ can not be estimated separately if the two vectors $X_{1}$ and $X_{2}$ are proportional. Hence, the following identification condition must hold

$$
\left(\frac{\sigma_{\epsilon, c}^{2}+\sigma_{\epsilon, r}^{2}}{\sigma_{\epsilon, j}^{2}+\sigma_{\epsilon, r}^{2}}\right) \neq\left(\frac{\sigma_{\delta, c}^{2}+\sigma_{\delta, r}^{2}}{\sigma_{\delta, j}^{2}+\sigma_{\delta, r}^{2}}\right)
$$

where $c, r$ and $j$ denote different countries. In words, there must be some differences in the relative variances of the demand and supply curves across countries.
} 
imported product category of each country. Summary statistics of these ratios are presented in Table 7: for example, the median lambda ratio ${ }^{12}$ for Ireland is $0.96<1$, expressing that the typical imported product category in Ireland experienced a positive variety growth of about $4 \% .{ }^{13}$ Using the lambda ratios as a measure of variety growth is more sophisticated than just counting new and disappearing varieties, as shown previously in Table 4. This measure also accounts for the importance of different varieties to the consumer budget decision by using expenditure shares as weights. ${ }^{14}$

Table 7: Lambda ratios

\begin{tabular}{lrrrrr}
\hline \hline & Nobs & Mean & Median & $5 \%$ & $95 \%$ \\
\hline France & 1797 & 1.82 & $\mathbf{0 . 9 9}$ & 0.43 & 1.83 \\
Germany & 1574 & 1.47 & $\mathbf{0 . 9 9}$ & 0.38 & 1.93 \\
Great Britain & 1306 & 2.07 & $\mathbf{0 . 9 8}$ & 0.31 & 1.80 \\
Italy & 1630 & 1.63 & $\mathbf{0 . 9 8}$ & 0.33 & 1.90 \\
\hline Austria & 1438 & 2.47 & $\mathbf{0 . 9 9}$ & 0.36 & 2.18 \\
Belgium & 1622 & 4.33 & $\mathbf{0 . 9 8}$ & 0.30 & 2.06 \\
Denmark & 1099 & 1.74 & $\mathbf{0 . 9 7}$ & 0.27 & 2.11 \\
Finland & 1208 & 2.02 & $\mathbf{0 . 9 7}$ & 0.18 & 2.83 \\
Greece & 1173 & 1.36 & $\mathbf{0 . 9 5}$ & 0.19 & 2.28 \\
Ireland & 1321 & 2.27 & $\mathbf{0 . 9 6}$ & 0.23 & 3.14 \\
Luxemburg & 1269 & 1.94 & $\mathbf{1 . 0 0}$ & 0.28 & 1.93 \\
Netherlands & 1457 & 4.70 & $\mathbf{0 . 9 8}$ & 0.23 & 2.31 \\
Portugal & 1243 & 2.90 & $\mathbf{0 . 9 9}$ & 0.27 & 2.45 \\
Spain & 1416 & 1.69 & $\mathbf{0 . 9 6}$ & 0.21 & 2.06 \\
Sweden & 1227 & 3.12 & $\mathbf{0 . 9 7}$ & 0.28 & 2.05 \\
\hline Bulgaria & 682 & 1.31 & $\mathbf{0 . 8 1}$ & 0.11 & 2.30 \\
Cyprus & 506 & 1.77 & $\mathbf{0 . 9 7}$ & 0.17 & 3.75 \\
Czech Republic & 247 & 2.08 & $\mathbf{0 . 9 8}$ & 0.22 & 2.84 \\
Estonia & 720 & 7.01 & $\mathbf{0 . 9 0}$ & 0.13 & 3.12 \\
Hungary & 768 & 10.27 & $\mathbf{1 . 0 0}$ & 0.21 & 3.55 \\
Latvia & 656 & 1.59 & $\mathbf{0 . 7 9}$ & 0.09 & 3.11 \\
Lithuania & 814 & 1.35 & $\mathbf{0 . 8 3}$ & 0.08 & 2.29 \\
Malta & 542 & 2.31 & $\mathbf{1 . 0 0}$ & 0.17 & 6.27 \\
Poland & 1232 & 11.59 & $\mathbf{0 . 9 9}$ & 0.21 & 3.34 \\
Romania & 874 & 7.86 & $\mathbf{0 . 8 6}$ & 0.13 & 3.05 \\
Slovakia & 853 & 3.83 & $\mathbf{0 . 9 6}$ & 0.17 & 2.73 \\
Slovenia & 993 & 1.96 & $\mathbf{0 . 9 7}$ & 0.24 & 2.92 \\
\hline \hline
\end{tabular}

Note: Goods are defined at the HS-8 level.

The summary statistics of the lambda ratios show that, for the largest four EU members, the growth in imported variety has been moderate, with median lambda ratios of 0.98 and 0.99 , indicating a weighted variety growth of $1 \%$ or $2 \%$. For the "small old" member states: the median lambda ratios are on average slightly lower, ranging from 0.95 in the case of Greece to 1.00 for Luxemburg, indicating that the variety growth ranges from $0 \%$ to $5 \%$ in this country group, while for most of these countries, the observed variety growth lies between $3 \%$ and $4 \%$. The "new" member states have experienced an even larger increase in imported varieties. The descriptive statistics of Section 2 hinted at this result already, but it is now confirmed by the lambda ratios: the median lambda ratio can be as low as 0.79 , as in the case of Latvia or 0.83 in Lithuania, indicating a variety growth of about $25 \%$. Exceptions are Malta, Hungary, and Poland with median lambda ratios of 1.00 or 0.99 and therefore with only small or zero growth in imported variety. From the quantiles it is also obvious that there is substantial variation across products and countries, emphasizing the importance of using product-specific measures to calculate accurate gains from imported varieties.

It is important to understand that this growth in variety does not directly lead to consumer gains. Most importantly, the degree of differentiation within the different product categories is crucial to the consumers: to make a simple example, it is not important to consumers how many different varieties of car fuel are available. Fuel is a very homogeneous good, thus it does probably not matter to the consumer whether it is imported from Norway, Nigeria, Saudi Arabia, or from all three countries. Within a CES

\footnotetext{
${ }^{12}$ Here the mean can be somewhat misleading due to the existence of outliers reaching high absolute values.

${ }^{13}$ Calculated as $1 / 0.96=4.2 \%$.

${ }^{14}$ There are fewer lambda ratios than product groups: Some lambda ratios cannot be defined at the HS- 8 level since there is no common variety at the beginning and the end of the chosen time period. We then follow Broda and Weinstein (2006) and define the lambda ratio at the SITC-5 level.
} 
framework, this homogeneity is expressed by a high value of the elasticity of substitution. Considering equation (6), it is obvious that for a high value of the elasticity of substitution for a specific product group the second term on the right hand side will converge to one. In this case, the price index is not being corrected and the consumers do not gain from the additional varieties (or lose from the disappearing ones). On the other hand, consumers do care about different varieties within a very differentiated product group, say for example trainers, furniture, or cars. Expectedly, these product categories exhibit low elasticities of substitution and therefore new varieties lower the price index substantially. As a next step, we estimate the elasticities of substitution for every imported product category of each country following our system of equations (18). Table 8 reports descriptive statistics of the estimated elasticities. $^{15}$

Table 8: Estimated elasticities of substitution

\begin{tabular}{lrrrrrr}
\hline \hline & \multicolumn{1}{c}{ Nobs } & \multicolumn{1}{c}{ Mean } & \multicolumn{1}{c}{ StE } & Median & Maximum & Minimum \\
\hline France & 10,491 & 11.29 & 0.83 & $\mathbf{4 . 2 2}$ & $5,504.26$ & 1.02 \\
Germany & 10,193 & 14.19 & 2.63 & $\mathbf{4 . 6 8}$ & $21,469.27$ & 1.04 \\
Great Britain & 9,930 & 10.46 & 1.47 & $\mathbf{3 . 8 4}$ & $11,977.77$ & 1.00 \\
Italy & 9,797 & 14.28 & 1.42 & $\mathbf{4 . 6 0}$ & $8,177.53$ & 1.01 \\
\hline Austria & 8,317 & 9.60 & 1.41 & $\mathbf{3 . 7 0}$ & $11,062.26$ & 1.02 \\
Belgium & 9,338 & 8.53 & 0.40 & $\mathbf{4 . 1 0}$ & $2,633.42$ & 1.00 \\
Denmark & 7,631 & 7.94 & 0.55 & $\mathbf{3 . 4 2}$ & $3,033.52$ & 1.03 \\
Finland & 6,765 & 14.23 & 2.00 & $\mathbf{4 . 0 4}$ & $12,064.90$ & 1.01 \\
Greece & 6,728 & 9.04 & 0.72 & $\mathbf{3 . 4 1}$ & $2,928.15$ & 1.00 \\
Ireland & 6,210 & 10.80 & 1.29 & $\mathbf{3 . 4 7}$ & $5,561.19$ & 1.00 \\
Luxemburg & 5,173 & 13.70 & 1.40 & $\mathbf{3 . 5 1}$ & $4,055.22$ & 1.00 \\
Netherlands & 8,698 & 16.90 & 3.81 & $\mathbf{4 . 3 8}$ & $29,244.75$ & 1.03 \\
Portugal & 7,182 & 12.03 & 1.47 & $\mathbf{3 . 6 5}$ & $6,326.31$ & 1.00 \\
Spain & 9,179 & 9.05 & 0.53 & $\mathbf{3 . 8 9}$ & $2,811.72$ & 1.00 \\
Sweden & 7,723 & 289.95 & 280.12 & $\mathbf{4 . 3 2}$ & $2,163,410.00$ & 1.00 \\
\hline Bulgaria & 5,314 & 12.63 & 1.30 & $\mathbf{4 . 5 7}$ & $5,875.99$ & 1.01 \\
Cyprus & 2,815 & 27.81 & 8.74 & $\mathbf{4 . 5 6}$ & $21,620.79$ & 1.02 \\
Czech Republic & 7,526 & 13.54 & 1.84 & $\mathbf{4 . 3 3}$ & $10,539.79$ & 1.00 \\
Estonia & 4,697 & 97.25 & 80.31 & $\mathbf{4 . 1 8}$ & $376,959.60$ & 1.00 \\
Hungary & 6,914 & 13.61 & 0.94 & $\mathbf{4 . 5 2}$ & $3,224.69$ & 1.01 \\
Latvia & 4,542 & 13.16 & 1.49 & $\mathbf{4 . 3 3}$ & $4,371.04$ & 1.01 \\
Lithuania & 5,138 & 13.46 & 2.32 & $\mathbf{4 . 5 0}$ & $11,296.21$ & 1.01 \\
Malta & 2,093 & 8.89 & 0.69 & $\mathbf{3 . 5 9}$ & 794.74 & 1.00 \\
Poland & 8,129 & 13.02 & 1.19 & $\mathbf{4 . 3 1}$ & $5,560.56$ & 1.01 \\
Romania & 6,437 & 15.85 & 2.49 & $\mathbf{4 . 8 9}$ & $15,217.73$ & 1.01 \\
Slovakia & 6,189 & 10.60 & 0.77 & $\mathbf{3 . 9 8}$ & $3,034.62$ & 1.00 \\
Slovenia & 6,329 & 11.71 & 1.83 & $\mathbf{4 . 0 7}$ & $10,740.02$ & 1.00 \\
\hline \hline & & & & & & \\
Note: Elastia & & & & & \\
\end{tabular}

Note: Elasticities are estimated at the goods level, which is defined at the HS-8 level.

Our estimation of the elasticities of substitutions reveals median elasticities between 3.4 and 4.9 in the different countries. They are of a similar magnitude to those in other contributions, for example in Broda and Weinstein (2006), Broda et al. (2006) or, Berry et al. (1995). Based on the assumption of a Krugman type economy, this translates into median mark-ups of between $42 \%$ and $25 \%$. Note that the means are heavily influenced by some outlier elasticities since the elasticities are bounded from below by 1 but are not bounded from above. However, these outliers do not affect our overall results of the gains from variety: high elasticities just indicate very homogeneous goods that have no impact on the price index in equation (6). Our results also show that there are no apparent systematic differences between median elasticities across different countries: for example between small and large countries or between "old" and "new" member states. This is interesting given the different structures of European Union economies in terms of size, growth rate and development and does not support theoretical predictions, as for example in Melitz and Ottaviano (2008). Furthermore, we test whether our estimated elasticities make sense from a practical view and therefore categorize the elasticities after the classification of Rauch

\footnotetext{
${ }^{15}$ A total of 2,093 estimated elasticities in Malta may seem like too few considering that this country imported 5,517 goods in 1999. However, some product categories in very small countries are imported from very few trading partners and for only a very short time span. For these goods it is not possible to estimate the elasticity of substitution. We drop these product categories. See Feenstra (1994) for more information about this estimation technique. Note that this is only a serious issue in the case of Malta and Cyprus, two small and somehow untypical "new" member states. We decided to report the results all the same.
} 
(1999). ${ }^{16}$ We find that our estimates fit the expectations well: homogeneous product categories exhibit a median elasticity of 4.8 , reference priced products of 4.3 , and homogenous products of $4.0 .{ }^{17} \mathrm{Using}$ our estimated elasticities of substitution and the lambda ratios we can calculate corrected price indices following equation (6) for each of the product categories. Following equation (9), these indices can be aggregated into a corrected import price index. The ratio of the conventional import price index and the corrected import price index then results in the EPR as displayed by equation (10). It is worth explaining the intuition behind this EPR: if this fraction is lower than 1, it means that the changing set of imported varieties has lowered the import price index. In that case, the consumers profit from lower unit costs of imports. These lower costs are the source of the welfare gains. On the other hand, if the EPR is above 1, the import price index is increased by the changing variety set. Thus, the disappearing varieties are more important to the consumers than the new varieties and the result will be a welfare loss. Said differently, if we calculate $(1 / E P R)-1$, we obtain the bias of the conventional import price index; if the bias is positive there is an upward bias and if it is negative there is a downward bias in the conventional price index. The EPR and the upward bias of the conventional import price index are displayed in columns 1 and 2 of Table 9 .

Table 9: Import Price Index Bias and the Gains from Variety

\begin{tabular}{lrrrr}
\hline \hline & EPR & Bias & Import Share & GFV \\
\hline France & 1.017 & $\mathbf{- 1 . 6 7 \%}$ & 0.24 & $\mathbf{- 0 . 4 0 \%}$ \\
Germany & 1.001 & $\mathbf{- 0 . 1 3 \%}$ & 0.26 & $\mathbf{- 0 . 0 3 \%}$ \\
Great Britain & 0.996 & $\mathbf{0 . 4 1 \%}$ & 0.21 & $\mathbf{0 . 0 9 \%}$ \\
Italy & 0.992 & $\mathbf{0 . 7 6 \%}$ & 0.21 & $\mathbf{0 . 1 6 \%}$ \\
\hline Austria & 0.992 & $\mathbf{0 . 8 3 \%}$ & 0.41 & $\mathbf{0 . 3 4 \%}$ \\
Belgium & 0.994 & $\mathbf{0 . 6 0 \%}$ & 0.84 & $\mathbf{0 . 5 0 \%}$ \\
Denmark & 0.975 & $\mathbf{2 . 4 7 \%}$ & 0.30 & $\mathbf{0 . 7 4 \%}$ \\
Finland & 1.002 & $\mathbf{- 0 . 2 3 \%}$ & 0.29 & $\mathbf{- 0 . 0 7 \%}$ \\
Greece & 0.985 & $\mathbf{1 . 5 4 \%}$ & 0.25 & $\mathbf{0 . 3 8 \%}$ \\
Ireland & 0.996 & $\mathbf{0 . 4 3 \%}$ & 0.38 & $\mathbf{0 . 1 6 \%}$ \\
Luxemburg & 1.000 & $\mathbf{- 0 . 0 5 \%}$ & 0.56 & $\mathbf{- 0 . 0 3 \%}$ \\
Netherlands & 0.992 & $\mathbf{0 . 7 9 \%}$ & 0.51 & $\mathbf{0 . 4 0 \%}$ \\
Portugal & 0.992 & $\mathbf{0 . 8 3 \%}$ & 0.34 & $\mathbf{0 . 2 8 \%}$ \\
Spain & 0.978 & $\mathbf{2 . 1 9 \%}$ & 0.26 & $\mathbf{0 . 5 9 \%}$ \\
Sweden & 0.993 & $\mathbf{0 . 7 5 \%}$ & 0.30 & $\mathbf{0 . 2 3 \%}$ \\
\hline Bulgaria & 0.971 & $\mathbf{2 . 9 4 \%}$ & 0.53 & $\mathbf{1 . 5 9 \%}$ \\
Cyprus & 0.985 & $\mathbf{1 . 5 3 \%}$ & 0.38 & $\mathbf{0 . 5 8 \%}$ \\
Czech Republic & 0.986 & $\mathbf{1 . 4 4 \%}$ & 0.65 & $\mathbf{0 . 9 5 \%}$ \\
Estonia & 0.964 & $\mathbf{3 . 5 8 \%}$ & 0.76 & $\mathbf{2 . 8 0 \%}$ \\
Hungary & 0.982 & $\mathbf{1 . 8 3 \%}$ & 0.62 & $\mathbf{1 . 1 5 \%}$ \\
Latvia & 0.969 & $\mathbf{3 . 0 6 \%}$ & 0.52 & $\mathbf{1 . 6 4 \%}$ \\
Lithuania & 0.977 & $\mathbf{2 . 2 8 \%}$ & 0.60 & $\mathbf{1 . 4 0 \%}$ \\
Malta & 1.023 & $\mathbf{- 2 . 3 2 \%}$ & 0.69 & $\mathbf{- 1 . 5 6 \%}$ \\
Poland & 0.990 & $\mathbf{0 . 9 7 \%}$ & 0.35 & $\mathbf{0 . 3 4 \%}$ \\
Romania & 0.973 & $\mathbf{2 . 7 4 \%}$ & 0.43 & $\mathbf{1 . 2 1 \%}$ \\
Slovakia & 0.971 & $\mathbf{2 . 9 3 \%}$ & 0.79 & $\mathbf{2 . 3 7 \%}$ \\
Slovenia & 0.980 & $\mathbf{1 . 9 9 \%}$ & 0.60 & $\mathbf{1 . 2 0 \%}$ \\
\hline \hline & & & & \\
\hline
\end{tabular}

Note: Estimates are based on the definition of a good at the HS8 level. A variety is defined as a particular good from a particular country.

The biases in the "big four" countries are relatively small in magnitude. In France, the change in the imported variety increases the import price index by $1.67 \%$ over the whole period, that is, consumers actually suffer from a slight decrease in the choice of different varieties. In Germany, this decrease is also present but very close to zero, thus we do not observe a relevant change in the set of varieties from the perspective of consumers in this country. In Great Britain and Italy, on the other hand, the newly imported varieties lead to a slight decrease in the import price index. Considering the "small old" economies of the European Union, we observe that the import price indices decrease due to the

\footnotetext{
${ }^{16}$ Rauch (1999) classifies goods as homogeneous if they are traded on organized exchanges, as reference priced if the goods can be identified by referring to list prices meaning that prices can be quoted without mentioning the name of the manufacturer, and as differentiated if products differ over a multitude of dimensions including for example a brand name or the place of selling.

${ }^{17}$ This also holds for the individual countries in our data set.
} 
new varieties in all the countries except in the cases of Finland and Luxembourg. The magnitude of this decrease is a bit larger on average than in the larger countries, with Denmark, Greece, and Spain experiencing a decrease of more than $1.5 \%$ in the import price index over the considered time span. The more accented differences can be observed if we consider the "new" members: in all these countries, with the exception of Malta, the change in the variety set translates into lower import prices. Furthermore, the magnitude of the correction in the price index is much larger, with Estonia and Latvia experiencing lower import prices of over 3\%, while in Bulgaria, Lithuania, Romania, and Slovakia, the bias is larger than $2 \%$. For Poland we observe the lowest positive bias with $0.97 \%$, while in all the other countries it is larger than $1 \%$.

The bias in the import price index quantifies the drop in import prices due to newly imported varieties. To obtain the total gains for consumers in relation to the total economic activity, we have to weight these price decreases (or increases) by the share of imports on this total activity. Based on the assumption of a Krugman style economy, we compute the gains from variety as a fraction of GDP as in equation (11). In column 3 of Table 9 we report the import share of each country and in column 4 we calculate the gains from variety (GFV). The GFV can be interpreted in the following way: for an example, the EPR in the Netherlands is 0.992, indicating an upward bias in the conventional price index of $0.79 \%$ over the whole period. Weighting this bias by the import share of $51 \%$ results in an overall gain from variety through imports of $0.40 \%$ of GDP. Put differently, consumers in the Netherlands are willing to spend $0.40 \%$ of their GDP in the year 2008 to have access to the larger set of imported varieties of 2008 instead of the set of 1999. Not surprisingly, the smaller countries in the sample exhibit higher import shares, a fact well documented in the literature. ${ }^{18}$ Also note that the "new" member states exhibit a large dependence on imports, mostly between $50 \%$ and $80 \%$ of GDP.

The differences in import shares in combination with the correct import price indices result in a particular pattern of the GFV. The gains from variety in the "big four" of the European Union are very small. In France, a loss in variety of $0.40 \%$ of GDP occurs, while in the other three countries the gains or losses are closely around zero. Regarding the "small old" members, we observe that the gains from variety are strongly positive in most cases and around $0.5 \%$ of GDP. In this subgroup consumers of Denmark and Spain enjoyed the highest gains relative to GDP with $0.74 \%$ and $0.59 \%$. The exceptions are Finland and Luxemburg which basically neither gain nor lose from the changed variety set. Again, the results for the "new" members of the European Union are the most striking ones. In nearly all the countries, the GFV surpass 1\% of GDP. The consumers in Estonia gained 2.80\% of GDP in the last 10 years by the increased imported variety. High GFV above $1.5 \%$ of GDP are also found in Bulgaria, Latvia and Slovakia. Hungary, Lithuania, Romania, and Slovenia exhibit modest gains that still lie above 1\% of GDP. In Cyprus and Malta, the gains are small or even negative, a result of their dependence on only a few trading partners like Italy or France. In Poland on the other hand, the small GFV of only $0.34 \%$ of GDP are a result of the relatively low import share.

\subsection{Geographical Origin of the Variety Gains from Trade}

We are now interested in the question of where these GFV come from geographically. In particular, we would like to know whether the majority of these gains stems from trade with other European Union economies, or whether other countries, addressed here as "Rest of the World" (ROW) contribute a substantial share to these gains. The methodology used and presented in section 3 allows us to compute the EPR for each trading partner, or, more appropriately here, the EPR stemming from trade with a group of countries. For each country group $i$, in our case the European Union and ROW; thus $i=E U, R O W$, the EPR is computed as follows:

$$
E P R_{i}=\prod_{g}\left[\left(\frac{\lambda_{g t}}{\lambda_{g t-1}}\right)^{\left(w_{g t} /\left(\sigma_{g-1}\right)\right) W_{i g t}}\right],
$$

where $W_{i g t}$ is the ideal log-change weight of country group $i$ on good $g$. Note that, in multiplying all these $E P R_{i}$ 's, the total $E P R$ as reported in Table 9 results:

$$
E P R=E P R_{E U} E P R_{R O W}
$$

\footnotetext{
${ }^{18}$ In fact, the variation of import shares is one of the only significant differences between small and large countries that can be well documented, according to Rose (2006).
} 
The bias in the price index can then be calculated as described above and the results for the $27 \mathrm{EU}$ members are depicted in Table 10. Column 1 and 2 depict the EPR ratio resulting from the imports from other EU member states and from the ROW, respectively while columns 3 and 4 display the bias in the import price index resulting from these imports. For example, German consumers very slightly gain from the change in the variety set imported from its European trading partners (a decrease in the price index of $0.02 \%$, as depicted in column 3) but lose from the change in imported variety of its ROW partners (an increase of $0.15 \%$ in the price index as displayed in column 4). In Estonia, the country with the largest gains from variety, the bias in the price index for imports from other EU members amounts to $2.89 \%$ while the bias stemming from imports of ROW countries accounts for only $0.66 \%$. This pattern can be observed for many countries, old as well new member states. All these countries experience lower import price indices through both, imports from other European Union members and from ROW countries. However, in all these countries, the upward bias is much higher for the European imports. Some other countries as for example the Czech Republic or Ireland gain from the the higher variety from intra-European trade but lose part of these gains due to the lower variety imported from ROW countries. In Finland, this loss even dominates the gains due to imports from the European Union. The only exception is France, which experiences variety losses in imports from both blocks.

Table 10: Geographical origin of the Gains from Variety

\begin{tabular}{lcc|rr}
\hline \hline & \multicolumn{2}{c|}{ EPR } & \multicolumn{2}{c}{ Bias } \\
& EU & ROW & EU & ROW \\
\hline France & 1.009 & 1.008 & $\mathbf{- 0 . 8 7 \%}$ & $\mathbf{- 0 . 7 9 \%}$ \\
Germany & 1.000 & 1.002 & $\mathbf{0 . 0 2 \%}$ & $\mathbf{- 0 . 1 5 \%}$ \\
Great Britain & 0.996 & 1.000 & $\mathbf{0 . 3 6 \%}$ & $\mathbf{0 . 0 5 \%}$ \\
Italy & 0.995 & 0.998 & $\mathbf{0 . 5 3 \%}$ & $\mathbf{0 . 2 4 \%}$ \\
\hline Austria & 0.993 & 0.999 & $\mathbf{0 . 7 2 \%}$ & $\mathbf{0 . 1 1 \%}$ \\
Belgium & 0.994 & 1.000 & $\mathbf{0 . 5 6 \%}$ & $\mathbf{0 . 0 3 \%}$ \\
Denmark & 0.979 & 0.996 & $\mathbf{2 . 0 7 \%}$ & $\mathbf{0 . 4 2 \%}$ \\
Finland & 0.998 & 1.004 & $\mathbf{0 . 1 7 \%}$ & $\mathbf{- 0 . 4 0 \%}$ \\
Greece & 0.984 & 1.001 & $\mathbf{1 . 6 0 \%}$ & $\mathbf{- 0 . 0 6 \%}$ \\
Ireland & 0.989 & 1.007 & $\mathbf{1 . 1 2 \%}$ & $\mathbf{- 0 . 6 9 \%}$ \\
Luxemburg & 0.996 & 1.002 & $\mathbf{0 . 3 8 \%}$ & $\mathbf{- 0 . 1 8 \%}$ \\
Netherlands & 0.995 & 0.997 & $\mathbf{0 . 5 0 \%}$ & $\mathbf{0 . 3 0 \%}$ \\
Portugal & 0.994 & 0.998 & $\mathbf{0 . 6 3 \%}$ & $\mathbf{0 . 2 0 \%}$ \\
Spain & 0.988 & 0.990 & $\mathbf{1 . 2 1 \%}$ & $\mathbf{0 . 9 9 \%}$ \\
Sweden & 0.994 & 0.999 & $\mathbf{0 . 6 2 \%}$ & $\mathbf{0 . 1 3 \%}$ \\
\hline Bulgaria & 0.976 & 0.994 & $\mathbf{2 . 3 8 \%}$ & $\mathbf{0 . 5 7 \%}$ \\
Cyprus & 0.988 & 0.997 & $\mathbf{1 . 2 4 \%}$ & $\mathbf{0 . 2 9 \%}$ \\
Czech Republic & 0.985 & 1.000 & $\mathbf{1 . 4 6 \%}$ & $\mathbf{- 0 . 0 2 \%}$ \\
Estonia & 0.971 & 0.993 & $\mathbf{2 . 8 9 \%}$ & $\mathbf{0 . 6 6 \%}$ \\
Hungary & 0.985 & 0.996 & $\mathbf{1 . 4 7 \%}$ & $\mathbf{0 . 3 6 \%}$ \\
Latvia & 0.976 & 0.994 & $\mathbf{2 . 4 4 \%}$ & $\mathbf{0 . 6 3 \%}$ \\
Lithuania & 0.982 & 0.995 & $\mathbf{1 . 7 9 \%}$ & $\mathbf{0 . 4 9 \%}$ \\
Malta & 1.020 & 1.003 & $\mathbf{- 2 . 0 1 \%}$ & $\mathbf{- 0 . 3 0 \%}$ \\
Poland & 0.991 & 0.999 & $\mathbf{0 . 8 6 \%}$ & $\mathbf{0 . 1 1 \%}$ \\
Romania & 0.976 & 0.997 & $\mathbf{2 . 4 3 \%}$ & $\mathbf{0 . 3 2 \%}$ \\
Slovakia & 0.973 & 0.997 & $\mathbf{2 . 6 7 \%}$ & $\mathbf{0 . 2 7 \%}$ \\
Slovenia & 0.982 & 0.998 & $\mathbf{1 . 8 3 \%}$ & $\mathbf{0 . 1 8 \%}$ \\
\hline \hline
\end{tabular}

Note: Estimates are based on the definition of a good at the HS8 level. A variety is defined as a particular good from a particular country.

\subsection{Interpretation of the Results}

Our results can be summarized as follows: the average bias of the import price index for the "big four" is slightly negative at $-0.18 \% .{ }^{19}$ Consumers in the four largest economies of the EU consequently lose slightly from the change in the set of imported varieties and this loss stems from trade with the ROW countries. For the "smaller old" member states we estimate positive gains with an average of $1.24 \%$. Although these countries have profited from both internal and external imports our results show that more than $70 \%$ of the gains can be attributed to within European trade. This is interesting, given

\footnotetext{
${ }^{19}$ We calculated the weighted average bias of the import price index using the size of each country in term of its GDP. This is done to obtain a clearer picture of the differences between the three country blocks.
} 
our somewhat different results from section 2, where we find a strong increase in the number of newly imported varieties from non-European members but at the same time observed only a modest increase in imported varieties from trade within Europe. This fact again underlines our approach to take into account the weights of each product in the consumption decision instead of simply counting the number of new varieties. Finally, for the "new" member states, we find a large average bias in the import price index of $1.68 \%$. These countries have benefited substantially from internal European trade over the last decade, which accounts for $90 \%$ of the total gains from imported varieties.

One explanation for this pattern of the gains from variety makes use of the ongoing process of European integration as well as globalization in general: the "big four" countries were already playing a key role in the global economy at the beginning of our period and had well- established trade links as well within the European Union as well as within the global trading system. Consequently, access to new varieties via new trade linkages has been limited, given their already diverse structure of imports in 1999 . Hence, we observe that most trade has been growing at the intensive margin, resulting in relatively low gains. Besides these reasons, the smaller import shares also play a role in these countries. In addition, some trade diversion from ROW towards the European Union may have taken place, adding another possible explanation for our slightly negative results for some of these countries especially concerning imports from ROW.

For the high income "small old" member states, we observed in section 2 that their import diversity is somewhat more limited compared with the largest countries. The increase over the last decade has been more substantial and their large import shares make imports, and the imported variety in particular, an important source of welfare gains. Nonetheless, the trading of these countries with other European members was already well diversified by the year 1999 and especially the European Union has been an important source of imports for decades. Furthermore, most of these countries have been part of the European Union for a longer period and had already adopted important institutions like the single market programme before 1999. This in combination with the proximity to the other member states can explain the slower growth rate of new trade linkages within the European trade network compared with the "new" members.

These "new" member countries, on the other hand, were less integrated into the world trading system in 1999 and consequently have taken advantage of the dynamic globalization process over the last decade to diversify and extend their imported product set at the global level. In contradiction to the stylized facts, however, our estimated results for the gains show that most of the gains stem from internal European imports. This can be reasoned by the fact that the new trade linkages from non-European members only had a minor impact on the gains from variety, due to their relatively small share of expenditure in the overall consumption bundle. Finally, our results reveal an expected process, namely that over the last decade, the new member states have caught up with the older ones, regarding the integration into the European market. Consequently, the European Union has been an important source of new products and varieties for these countries. With the reorientation of the transition economies towards "old" Europe in combination with the reduction in trade barriers and the adoption of important European Union institutions during the accession period, trade linkages of these countries with all the other EU-27 members have grown at a rapid rate, resulting in substantial consumer welfare gains due to the existence of a more diverse set of products and varieties.

\section{Robustness Checks}

Since our empirical approach rests on some strong assumptions we address four important issues to build further confidence in our results in this section. One issue is the dependence of the results on the estimated elasticities of substitution. Secondly, we would like to talk about the level of disaggregation of the trade data ans therefore about how a variety is defined. As a third point, we argue that we obtain welfare gains of consumers although we use all the imports to estimate the GFV instead of only imports of consumer goods. Fourth, since the methodology used above only focuses on imported varieties and neglects changes in the domestic variety, we provide a short discussion on how this effect may change our results. 


\section{The Degree of Substitutability}

Estimating elasticities of substitution from trade data is not an easy task. Due to the data restrictions, several strong assumptions have to be made to identify this parameter. It would be beyond the scope of this paper to discuss this in detail. ${ }^{20}$ However, we would like to assess the impact of potential biases on the variety gains from trade.

Table 11: Robustness of the results using different values for the elasticity of substitution

\begin{tabular}{lr|rr|rrrr}
\hline \hline & \multicolumn{1}{c}{$\hat{\sigma}$} & $+50 \%$ & $-50 \%$ & $\sigma=2$ & $\sigma=3$ & $\sigma=4$ & $\sigma=8$ \\
\hline France & $-1.67 \%$ & $-1.11 \%$ & $-3.37 \%$ & $-4.74 \%$ & $-2.34 \%$ & $-1.55 \%$ & $-0.66 \%$ \\
Germany & $-0.13 \%$ & $-0.09 \%$ & $-0.26 \%$ & $-0.56 \%$ & $-0.28 \%$ & $-0.19 \%$ & $-0.08 \%$ \\
Great Britain & $0.41 \%$ & $0.27 \%$ & $0.81 \%$ & $2.23 \%$ & $1.12 \%$ & $0.75 \%$ & $0.32 \%$ \\
Italy & $0.76 \%$ & $0.51 \%$ & $1.52 \%$ & $6.19 \%$ & $3.14 \%$ & $2.11 \%$ & $0.91 \%$ \\
\hline Austria & $0.83 \%$ & $0.56 \%$ & $1.66 \%$ & $3.16 \%$ & $1.59 \%$ & $1.06 \%$ & $0.46 \%$ \\
Belgium & $0.60 \%$ & $0.40 \%$ & $1.19 \%$ & $4.14 \%$ & $2.09 \%$ & $1.40 \%$ & $0.60 \%$ \\
Denmark & $2.47 \%$ & $1.66 \%$ & $4.89 \%$ & $5.99 \%$ & $3.04 \%$ & $2.04 \%$ & $0.88 \%$ \\
Finland & $-1.25 \%$ & $-0.83 \%$ & $-2.51 \%$ & $-4.13 \%$ & $-2.04 \%$ & $-1.36 \%$ & $-0.58 \%$ \\
Greece & $1.54 \%$ & $1.03 \%$ & $3.05 \%$ & $0.61 \%$ & $0.30 \%$ & $0.20 \%$ & $0.09 \%$ \\
Ireland & $0.43 \%$ & $0.29 \%$ & $0.87 \%$ & $0.74 \%$ & $0.37 \%$ & $0.25 \%$ & $0.11 \%$ \\
Luxemburg & $-0.05 \%$ & $-0.03 \%$ & $-0.07 \%$ & $3.05 \%$ & $1.54 \%$ & $1.03 \%$ & $0.44 \%$ \\
Netherlands & $0.79 \%$ & $0.53 \%$ & $1.58 \%$ & $5.35 \%$ & $2.71 \%$ & $1.82 \%$ & $0.78 \%$ \\
Portugal & $0.83 \%$ & $0.55 \%$ & $1.66 \%$ & $3.82 \%$ & $1.93 \%$ & $1.29 \%$ & $0.55 \%$ \\
Spain & $2.15 \%$ & $1.44 \%$ & $4.25 \%$ & $7.10 \%$ & $3.62 \%$ & $2.43 \%$ & $1.05 \%$ \\
Sweden & $0.75 \%$ & $0.50 \%$ & $1.49 \%$ & $4.89 \%$ & $2.48 \%$ & $1.66 \%$ & $0.71 \%$ \\
\hline Bulgaria & $2.94 \%$ & $1.97 \%$ & $5.80 \%$ & $17.83 \%$ & $9.35 \%$ & $6.34 \%$ & $2.77 \%$ \\
Cyprus & $1.53 \%$ & $1.02 \%$ & $3.04 \%$ & $6.95 \%$ & $3.54 \%$ & $2.37 \%$ & $1.02 \%$ \\
Czech Republic & $1.44 \%$ & $0.96 \%$ & $2.86 \%$ & $6.80 \%$ & $3.46 \%$ & $2.32 \%$ & $1.00 \%$ \\
Estonia & $3.58 \%$ & $2.40 \%$ & $7.04 \%$ & $13.54 \%$ & $7.02 \%$ & $4.73 \%$ & $2.06 \%$ \\
Hungary & $1.83 \%$ & $1.22 \%$ & $3.62 \%$ & $6.29 \%$ & $3.20 \%$ & $2.14 \%$ & $0.92 \%$ \\
Latvia & $3.06 \%$ & $2.05 \%$ & $6.02 \%$ & $14.06 \%$ & $7.30 \%$ & $4.93 \%$ & $2.14 \%$ \\
Lithuania & $2.28 \%$ & $1.52 \%$ & $4.50 \%$ & $11.05 \%$ & $5.68 \%$ & $3.83 \%$ & $1.66 \%$ \\
Malta & $-2.32 \%$ & $-1.61 \%$ & $-4.69 \%$ & $-7.90 \%$ & $-3.88 \%$ & $-2.57 \%$ & $-1.09 \%$ \\
Poland & $0.97 \%$ & $0.65 \%$ & $1.93 \%$ & $3.77 \%$ & $1.90 \%$ & $1.27 \%$ & $0.55 \%$ \\
Romania & $2.73 \%$ & $1.83 \%$ & $5.39 \%$ & $13.74 \%$ & $7.13 \%$ & $4.81 \%$ & $2.09 \%$ \\
Slovakia & $2.93 \%$ & $1.96 \%$ & $5.78 \%$ & $9.64 \%$ & $4.94 \%$ & $3.32 \%$ & $1.44 \%$ \\
Slovenia & $1.99 \%$ & $1.33 \%$ & $3.94 \%$ & $11.50 \%$ & $5.93 \%$ & $3.99 \%$ & $1.73 \%$ \\
\hline & & & & & & & \\
\hline & & & & & & \\
& & & & & & \\
& & & & &
\end{tabular}

Note: Elasticities are estimated at the goods level, which is defined at the HS-8 level.

The first column shows the results from above using the estimated elasticities $\hat{\sigma}$ while columns 2 and 3 show how the bias changes if we increase or decrease our estimates by $50 \%{ }^{21}$ The idea of this experiment is to assess whether a possible bias in the estimated elasticities can have a substantial effect on our results. Even though we assume a large upward and downward bias of $50 \%$ in every estimated elasticity, our results remain relatively constant. For some countries the bias quite expectedly becomes large if the much lower sigmas are used. ${ }^{22}$

In columns 4 to 7 of Table 11 we use a fixed value for the elasticities of substitution for all the product groups. We present these results here to demonstrate the potential bias of using a single value for all the elasticities of all the product groups. Consider for example Italy. With the estimated values of the sigmas (column 1), new varieties lower the import price index by $0.76 \%$. As Table 4 shows, the median sigma in Italy is 4.60 . However, using a similar elasticity of, say 4 , for each product results in a bias of $2.11 \%$, almost three times larger. Even if we use a common elasticity as high as 8 the bias is still higher than the results when using the estimated elasticities that vary for each product group $(0.91 \%$ compare with $0.76 \%$ ). Thus, if we are interested in finding the "true" gains from imported variety, it is of central importance to estimate the elasticities for each product category. To explain the differences in the results for the gains from variety between the fixed and the estimated elasticities of substitution

\footnotetext{
${ }^{20}$ Interested readers are referred to Feenstra (1991), which is the more detailed working paper version of Feenstra (1994), as well as to an appendix available on Robert C. Feenstra's website. Furthermore, Soderbery (2009) discussed some of the properties of this estimator.

${ }^{21}$ For example, if $\hat{\sigma}=1.5$, we use $\sigma_{u}=1.75$ as an upper bound and $\sigma_{l}=1.25$ as a lower bound. Thus, we first substract 1 from the estimate, then increase or decrease the remainder by $50 \%$ and then add 1 .

${ }^{22}$ Recall that lower values for the elasticity of substitution imply higher gains since consumers value the availability of new varieties more.
} 
consider the following example: when using the fixed values of sigma, highly homogenous products with a high import share and a high elasticity of substitution like gasoline will substantially bias the "true" gains from variety upwards given the misspecification of the elasticity of substitution when fixed values are used.

\section{The Definition of a Variety}

Next, we analyse the extent to which our results depend on the definition of a variety. This is of course a central issue: the more detailed the data, the higher the "turnover" of varieties and thus, potentially, the higher the gains from variety. Table 12 presents the results for different levels of aggregation of the data. The HTS-8 results from above are shown in column 1. As mentioned before, about 10.000 product categories are defined at that level. The EPRs of data at the HTS-6 level are presented in column 2. At this level of aggregation about 6.000 categories are defined. Column 3 then shows the results of HTS-4, which defines only slightly over 1.000 products. The bias and GFV for these levels of aggregation are then shown in columns 4 to 6 and 7 to 9 , respectively. Comparing the bias and the GFV of HTS-6 and HTS-8, we conclude that the results are sufficiently robust: for many countries, the bias is slightly lower using HTS-6 compared with using HTS-8, as expected. For other countries, however, this is just reversed. This result may be counterintuitive at first sight. However, this is perfectly possible since we also reestimate the elasticities of substitution at this level of aggregation. The median sigmas at the HTS-6 level are lower than those at the HTS-8 level (results omitted here). This is an intuitive result since more broadly defined product categories generally yield lower substitutability of the contained varieties. Hence, by using less disaggregated data, we may miss some variety growth: the varieties observed, however, are estimated as being more differentiated and therefore they contribute more to the gains from variety.

Table 12: Robustness of the results using different aggregation levels of the data

\begin{tabular}{lrrrrrr|rrr}
\hline \hline & HTS-8 & HTS-6 & HTS-4 & HTS-8 & HTS-6 & HTS-4 & HTS-8 & HTS-6 & HTS-4 \\
\hline France & 1.017 & 1.010 & 1.001 & $-1.67 \%$ & $-0.97 \%$ & $-0.12 \%$ & $-0.40 \%$ & $-0.23 \%$ & $-0.03 \%$ \\
Germany & 1.001 & 0.999 & 1.002 & $-0.13 \%$ & $0.14 \%$ & $-0.19 \%$ & $-0.03 \%$ & $0.04 \%$ & $-0.05 \%$ \\
Great Britain & 0.996 & 0.993 & 0.999 & $0.41 \%$ & $0.68 \%$ & $0.12 \%$ & $0.09 \%$ & $0.15 \%$ & $0.03 \%$ \\
Italy & 0.992 & 0.992 & 0.995 & $0.76 \%$ & $0.76 \%$ & $0.49 \%$ & $0.16 \%$ & $0.16 \%$ & $0.10 \%$ \\
\hline Austria & 0.992 & 0.992 & 0.997 & $0.83 \%$ & $0.75 \%$ & $0.27 \%$ & $0.34 \%$ & $0.31 \%$ & $0.11 \%$ \\
Belgium & 0.994 & 0.992 & 0.998 & $0.60 \%$ & $0.79 \%$ & $0.24 \%$ & $0.50 \%$ & $0.67 \%$ & $0.20 \%$ \\
Denmark & 0.975 & 0.976 & 0.986 & $2.47 \%$ & $2.37 \%$ & $1.40 \%$ & $0.74 \%$ & $0.71 \%$ & $0.42 \%$ \\
Finland & 1.002 & 0.994 & 0.998 & $-0.23 \%$ & $0.61 \%$ & $0.23 \%$ & $-0.07 \%$ & $0.18 \%$ & $0.07 \%$ \\
Greece & 0.985 & 0.984 & 0.984 & $1.54 \%$ & $1.62 \%$ & $1.57 \%$ & $0.38 \%$ & $0.41 \%$ & $0.39 \%$ \\
Ireland & 0.996 & 0.989 & 0.992 & $0.43 \%$ & $1.11 \%$ & $0.76 \%$ & $0.16 \%$ & $0.42 \%$ & $0.29 \%$ \\
Luxemburg & 1.000 & 0.984 & 0.964 & $-0.05 \%$ & $1.55 \%$ & $3.65 \%$ & $-0.03 \%$ & $0.88 \%$ & $2.11 \%$ \\
Netherlands & 0.992 & 0.993 & 0.996 & $0.79 \%$ & $0.71 \%$ & $0.44 \%$ & $0.40 \%$ & $0.36 \%$ & $0.23 \%$ \\
Portugal & 0.992 & 0.999 & 0.990 & $0.83 \%$ & $0.07 \%$ & $1.02 \%$ & $0.28 \%$ & $0.02 \%$ & $0.35 \%$ \\
Spain & 0.978 & 0.987 & 0.992 & $2.19 \%$ & $1.33 \%$ & $0.75 \%$ & $0.59 \%$ & $0.36 \%$ & $0.20 \%$ \\
Sweden & 0.993 & 0.991 & 0.996 & $0.75 \%$ & $0.86 \%$ & $0.40 \%$ & $0.23 \%$ & $0.26 \%$ & $0.12 \%$ \\
\hline Bulgaria & 0.971 & 0.978 & 0.976 & $2.94 \%$ & $2.18 \%$ & $2.37 \%$ & $1.59 \%$ & $1.18 \%$ & $1.28 \%$ \\
Cyprus & 0.985 & 0.969 & 0.982 & $1.53 \%$ & $3.06 \%$ & $1.81 \%$ & $0.58 \%$ & $1.17 \%$ & $0.69 \%$ \\
Czech Republic & 0.986 & 0.999 & 1.001 & $1.44 \%$ & $0.12 \%$ & $-0.13 \%$ & $0.95 \%$ & $0.08 \%$ & $-0.08 \%$ \\
Estonia & 0.964 & 0.966 & 0.981 & $3.58 \%$ & $3.36 \%$ & $1.93 \%$ & $2.80 \%$ & $2.62 \%$ & $1.48 \%$ \\
Hungary & 0.982 & 0.982 & 0.992 & $1.83 \%$ & $1.84 \%$ & $0.77 \%$ & $1.15 \%$ & $1.16 \%$ & $0.48 \%$ \\
Latvia & 0.969 & 0.969 & 0.985 & $3.06 \%$ & $3.10 \%$ & $1.52 \%$ & $1.64 \%$ & $1.66 \%$ & $0.81 \%$ \\
Lithuania & 0.977 & 0.984 & 0.986 & $2.28 \%$ & $1.65 \%$ & $1.44 \%$ & $1.40 \%$ & $1.01 \%$ & $0.88 \%$ \\
Malta & 1.023 & 1.017 & 1.009 & $-2.32 \%$ & $-1.67 \%$ & $-0.91 \%$ & $-1.56 \%$ & $-1.13 \%$ & $-0.62 \%$ \\
Poland & 0.990 & 0.995 & 0.995 & $0.97 \%$ & $0.50 \%$ & $0.47 \%$ & $0.34 \%$ & $0.18 \%$ & $0.16 \%$ \\
Romania & 0.973 & 0.979 & 0.988 & $2.74 \%$ & $2.13 \%$ & $1.22 \%$ & $1.21 \%$ & $0.94 \%$ & $0.53 \%$ \\
Slovakia & 0.971 & 0.982 & 0.995 & $2.93 \%$ & $1.76 \%$ & $0.46 \%$ & $2.37 \%$ & $1.41 \%$ & $0.36 \%$ \\
\hline \hline
\end{tabular}

Note: Different levels of product aggregation are based on the Hármonized system nomenclature of the World Customs Organization.

Considering the results using HTS-4, we observe that the bias is always much lower in magnitude compared with HTS-6 or HTS-8. With the restriction to only 1.000 product categories we lose much of the information of the variety change that actually occurs in the more disaggregated data. This effect also dominates the opposite effect of the slightly lower elasticities in the HTS-4 case (results omitted). 
Most importantly note that our results remain fairly constant in terms of relative size across countries. Hence our qualitative conclusions remain valid.

Ultimately, this leads to the question of what the optimal definition of a variety should be. Blonigen and Soderbery (2009) argue that the variety gains from trade as estimated above are underestimated since trade data hides some variety growth. They show, using very detailed market data of the U.S. autombile market, that the gains from variety are $50 \%$ higher if these more disaggregated data are used instead of standard trade data. In the same vein is a comment by Bernard et al. (2009), who argue that even new (and still very scarce) firm-level data would imply higher variety gains from trade, because since every firm produces different varieties instead of "just" every country. To sum up, our results presented above may be a lower bound and the actual gains may even be higher due to data limitations. On the other hand, Table 12 has also shown that an opposing force, namely the higher estimated elasticities of substitution exists, if more detailed data are used.

\section{The Effects on Domestically Produced Varieties}

One central issue remains to be discussed when speaking about the variety gains from trade. Using the model described in Section 2, we implicitly assume that domestic and foreign goods cannot be substituted. That is, a change in the variety of imported goods does not affect the domestic economy, or more specifically the variety of domestically produced goods. This is the same stark assumption as Broda and Weinstein (2006) use. It is not hard to find a model that addresses this issue theoretically. For example in Melitz (2003), more productive foreign firms crowd out the less productive domestic firms, leading to a decrease in domestically produced varieties. As Baldwin (2006) or Arkolakis et al. (2008) show, the total variety consumed in a country can even decrease after trade liberalization in such a model. ${ }^{23}$ Empirically, the effect on domestic production is harder to assess due to the lack of availability of disaggregated domestic production data.

In a very recent contribution however, Ardelean and Lugovskyy (2009) address this issue. They set up a simple model, where varieties can be substituted on two levels: on the first level, domestic varieties can be substituted with a constant elasticity. The same is possible within a foreign good. On the second level, foreign and domestic varieties are substitutable by another, sensibly a lower, elasticity of substitution. Thus, depending on the magnitude of the elasticities, foreign varieties could replace domestic varieties upon trade liberalization. The authors then quantify a potential bias that results from ignoring this possible substitution. Using data on U.S. manufacturing sectors, they find that in some sectors, such as electronics, the variety change is even underestimated by as much as $90 \%$. Thus, trade liberalization even led to a larger increase in variety if the domestic sector is taken into account. On the other hand, for other sectors, like machinery $\& 3$ transportation, the variety change is overestimated by $40 \%$ neglecting domestic variety. On average, the bias in the variety change is small, accounting for an overestimation of $8 \%$.

For our results presented above this means that the stark separation of domestic and foreign varieties does not lead to a systematic bias. Specifically, we do not systematically overestimate the gains from variety due to neglecting the effect on the domestic variety. We may overestimate the gains stemming from some product categories but underestimate the gains stemming from others. Whether this leads to a bias in total is difficult to say. Also, it is not easy to answer whether this potential bias is higher for some countries than for others. To address these important questions, further research, for example using more detailed data sets that are restricted to some product categories, is necessary but beyond the scope of this paper.

\section{Conclusion}

Over the last decade the member states of the European Union have been part of a dynamic economic integration process as well within the European Union as well as at the global level, resulting in a strong increase in imported products and varieties. In this paper we adopt the methodology outlined by Feenstra (1994) and Broda and Weinstein (2006) analyse and estimate the positive effects of variety growth on consumer welfare for all the European Union member states for the period from 1999 to 2008.

\footnotetext{
${ }^{23}$ Of course, one still had to weight these verieties by the expenditure shares and the degree of substitutability. Thus these results themselves do not imply that the gains from variety would be negative.
} 
Our results show that for most countries the import price index is biased upwards due to the omission of newly imported varieties. This gives rise to positive welfare gains to consumers stemming from an increased product variety. However, our analysis also reveals substantial differences across countries. Based on the assumption of a Krugman type economy, we can hardly identify any gains from newly imported varieties over the last decade for the largest four countries of the European Union. On the other hand, these gains are more significant for the smaller and especially younger member states of the European Union. Here, our results suggest positive welfare gains of up to $2.8 \%$ of GDP, as in the case of Estonia. This fact demonstrates that especially for smaller and fast-growing economies the creation and extension of trade linkages can be an important source of welfare, a fact often neglected in the discussion about the positive effects of globalization and economic integration.

To shed further light on the source of these gains, we develop an empirical strategy that allows us to identify the extent to which intra-EU and non-EU imports contribute to the gains from variety. Our analysis shows that between $70 \%$ and $100 \%$ can be attributed to increased variety imports from other European Union members. Imports from other countries did not contribute much to these gains; on the contrary, according to our results these imports often even contributed negatively, thus mitigating the positive effects of variety growth in the total imports. Thus, the ongoing integration of countries within the European Union positively benefits consumers with availability of an increased consumption set. Specifically, these predominantly stem from European varieties accentuating the economic benefits of the European integration process. Consequently, our empirical study is also interesting for future European Union accession candidates.

Finally, we provide a sensitivity analysis and conclude that our results are reasonably robust to other specifications. We show that the estimation of different elasticities of substitution for different product categories is a central issue. Additionally, using aggregated data may hide significant growth along the extensive margin leading to an underestimation of the gains from variety. While our study solely focuses on the consumption side, the methodology and data can also be easily implemented to analyse the positive effects of variety growth on production and productivity and may be an interesting field for future research. 


\section{References}

Ardelean, A., Lugovskyy, V., 2009. Domestic productivity and variety gains from trade. Journal of International Economics 80, 280-291.

Arkolakis, C., Demidova, S., Klenow, P. J., Rodríguez-Clare, A., 2008. Endogenous variety and the gains from trade. American Economic Review 98 (2), 444-450.

Armington, P. S., 1969. A theory of demand for products distinguished by place of production. International Monetary Fund Staff Papers 16, 159-178.

Baldwin, R., 2006. The euro's trade effect. ECB Working Paper Series 594.

Bernard, A. B., Eaton, J., Jensen, J. B., Kortum, S., 2003. Plants and productivity in international trade. American Economic Review 93 (4), 1268-1290.

Bernard, A. B., Jensen, J. B., Redding, S. J., Schott, P. K., 2009. The margins of U.S. trade. NBER Working Paper 14662.

Berry, S., Levinsohn, P., Pakes, A., 1995. Automobile prices in market equilibrium. Econometrica 63 (4), 841-890.

Besedes, T., Prusa, T. J., 2007. The role of extensive and intensive margins and export growth. NBER Working Paper 13628.

Bils, M., Klenow, P. J., 2001. The acceleration in variety growth. American Economic Review 91 (2), 274-280.

Blonigen, B. A., Soderbery, A., 2009. Measuring the benefits of product variety with an accurate variety set. NBER Working Paper 14956.

Broda, C., Greenfield, J., Weinstein, D. E., 2006. From groundnuts to globalization: A structural estimate of trade and growth. NBER Working Paper 12512.

Broda, C., Weinstein, D. E., 2004. Variety growth and world welfare. American Economic Review 94 (2), 139-144.

Broda, C., Weinstein, D. E., 2006. Globalization and the gains from trade. Quarterly Journal of Economics $121(2), 541-585$.

Buch, C., Piazolo, D., 2001. Capital and trade flows in europe and the impact of enlargement. Economic Systems 253, 183-214.

Chen, N., 2004. Intra-national versus international trade in the european union: Why do national borders matter? Journal of International Economics 63 (4), 93-118.

Diewert, W. E., 1976. Exact and superlative index numbers. Journal of Econometrics 4 (2), 115-145.

Dixit, A. K., Stiglitz, J. E., 1977. Monopolistic competition and optimum product diversity. American Economic Review 67 (3), 297-308.

Feenstra, R. C., 1991. New goods and index numbers: U.s. import prices. NBER Working Paper 1902.

Feenstra, R. C., 1992. How costly is protectionism? Journal of Economic Perspectives 6 (3), 159-178.

Feenstra, R. C., 1994. New product varieties and the measurement of international prices. American Economic Review 84 (1), 157-177.

Feenstra, R. C., Kee, H. L., 2008. Export variety and country productivity: Estimating the monopolistic competition model with endogenous productivity. Journal of International Economics 74 (2), 500-518.

Feenstra, R. C., Markusen, J. R., 1994. Accounting for growth with new inputs. International Economic Review 35 (2), 429-447. 
Funke, M., Ruhwedel, R., 2005. Export variety and economic growth in eastern european transition economies. Economics of Transition 13 (1), 25-50.

Hanson, G. H., 1998. Market potential, increasing returns, and geographic concentration, mimeo, University of Michigan.

Hausman, J. A., 1981. Exact consumer surplus and deadweight loss. American Economic Review 71 (4), 664-676.

Hausman, J. A., 1994. Valuation of new goods under perfect and imperfect competition. NBER Working Paper 4970 .

Hummels, D., Klenow, P. J., 2002. The variety and quality of a nation's exports. NBER Working Papers 8712 .

Kemp, M. C., 1962. Errors of measurement and bias in estimates of import demand parameters. Economic Record 38, 369-372.

Klenow, P. J., Rodríguez-Clare, A., 1997. Quantifying variety gains from trade liberalization, working Paper, University of Chicago.

Krugman, P. R., 1979. Increasing returns, monopolistic competition, and international trade. Journal of International Economics 9 (4), 469-479.

Krugman, P. R., 1980. Scale economies, product differentiation, and the pattern of trade. American Economic Review 70 (5), 950-959.

Krugman, P. R., 1981. Intraindustry specialization and the gains from trade. Journal of Political Economy 89 (5), 959-973.

Manchin, M., Pinna, A. M., 2009. Border effects in the enlarged eu erea: Evidence from imports to acession countries. Applied Economics 41 (14), 1835-1854.

Melitz, M. J., 2003. The impact of trade on intra-industry reallocations and aggregate industry productivity. Econometrica 71 (6), 1695-1725.

Melitz, M. J., Ottaviano, G. I. P., 2008. Market size, trade, and productivity. Review of Economic Studies 75 (1), 295-316.

Nitsch, V., 2000. National borders and international trade: Evidence from the european union. Canadian Journal of Economics 33 (4), 1091-1105.

Rauch, J. E., 1999. Networks versus markets in international trade. Journal of International Economics 48 (1), 7-35.

Romer, P. M., 1994. New goods, old theory, and the welfare costs of trade restrictions. Journal of Development Economics 43 (1), 5-38.

Rose, A. K., 2006. Size really doesn't matter: In search of a national scale effect. NBER Working Paper 12191.

Sato, K., 1976. The ideal log-change index number. Review of Economics and Statistics 58 (2), 223-228.

Smith, A., Venables, A., 1988. Completing the internal market in the european community. European Economic Review 32 (1), 1501-1525.

Soderbery, A., 2009. Investigating the asymptotic properties of import elasticity estimates, working Paper, University of California, Davis.

Spence, M., 1976. Product selection, fixed costs, and monopolistic competition. Review of Economic Studies 43 (2), 217-235. 
Trajtenberg, M., 1989. Welfare analysis of product innovations, with an application to computed tomography scanners. Journal of Political Economy 97 (2), 444-479.

Vartia, Y. O., 1976. Ideal log-change index numbers. Scandinavian Journal of Economics 3 (3), 121-126.

Yi, K.-M., 2003. Can vertical specialization explain the growth of world trade? Journal of Political Economy 111 (1), 52-102. 